\title{
Hydrochemical characteristics and quality assessment of groundwater in Amaravathi river basin of Karur district, Tamil Nadu, South India
}

\author{
A. Jafar Ahamed ${ }^{1}$ K. Loganathan ${ }^{1} \cdot$ R. Jayakumar ${ }^{2}$
}

Received: 24 March 2015 / Accepted: 2 September 2015/Published online: 16 September 2015

(C) Springer International Publishing 2015

\begin{abstract}
The hydrochemical study of groundwater in Karur district of the Amaravathi River basin has been carried out to assess the major ion chemistry and groundwater quality for domestic and drinking purposes. Twenty-four groundwater samples were collected, processed, and analyzed for various physico-chemical parameters such as $\mathrm{pH}$; electrical conductivity; total dissolved solids; total hardness; cations such as calcium, magnesium, sodium, and potassium; anions such as bicarbonate, chloride, sulfate, fluoride, nitrate, and phosphate in the laboratory using the standard methods given by the American Public Health Association (Standard methods for the examination of water and wastewater, 21st edn. American Public Health Association, Washington DC, 2005). For quality assessment, the results were compared with water quality standards prescribed by the Bureau of Indian standards (Indian standards specification for drinking water 15:10500. Bureau of Indian Standards, New Delhi, 2003) and World Health Organization (International standards for drinking water. World Health Organization, Geneva, 2005). All the groundwater samples in all three seasons (pre-monsoon, monsoon, and postmonsoon seasons) were not useful for drinking purposes owing to elevated levels of $\mathrm{Ca}^{2+}, \mathrm{Mg}^{2+}, \mathrm{Na}^{+}, \mathrm{HCO}_{3}{ }^{-}$, and $\mathrm{Cl}^{-}$. Karl Pearson correlation matrices for 14 variables were performed; EC, TDS, and TH had significant positive
\end{abstract}

A. Jafar Ahamed

agjafar@yahoo.co.in

1 Post Graduate and Research Department of Chemistry, Jamal Mohamed College (Autonomous) Affiliated to Bharathidasan University, Tiruchirappalli, Tamil nadu 620 020, India

2 Post Graduate and Research Department of Environmental Science, PSG College of Arts and Science (Autonomous) Affiliated to Bharathiar University, Coimbatore,

Tamil nadu 641 014, India correlations among themselves and also with $\mathrm{Ca}^{2+}, \mathrm{Mg}^{2+}$, $\mathrm{Na}^{+}$, and $\mathrm{Cl}^{-}$. $\mathrm{pH}$ shows negative correlation with most of the parameters. The piper trilinear diagram showed that groundwater in all three seasons falls into mixed $\mathrm{Ca}^{2+}$ $\mathrm{Mg}^{2+}-\mathrm{Cl}^{-}$type. Concerning water for irrigation purposes, parameters such as percent sodium ( $\% \mathrm{Na})$, sodium adsorption ratio (SAR), residual sodium carbonate (RSC), chloro-alkaline indices (CAI I and CAI II), permeability index (PI), magnesium hazard (MH), Kelley's ratio (KR), USSL diagram, Gibbs' ratio (GR), and Wilcox diagram were calculated on the basis of chemical data to evaluate the current status of groundwater in the Amaravathi River basin. Parameters like MH (74 \%), KR (75 \%), RSC (95\%), and PI (69\%) in all three seasons indicate that the samples are suitable for irrigation and remaining are unsuitable. From USSL diagram, the result reveals that the samples fall in C3S1 and C4-S1 indicate high to very high-salinity and lowsodium hazards. Wilcox diagram revealed out of 24 samples, sample no. 7, 8, and 11 in pre-monsoon, monsoon, and postmonsoon seasons fall under doubtful to unsuitable and 9 fall under unsuitable zone. The positive CAI values in $66 \%$ samples in all three seasons indicate reverse ion exchange mechanism. The present study may be helpful for further studies concerning water quality issues in this area, where groundwater is a vital for drinking and other activities.

Keywords Amaravathi River - Drinking use - Irrigation purpose $\cdot$ Karur $\cdot$ Salinity $\cdot$ Correlation matrix

\section{Introduction}

Analysis of any water resources system is crucial because of the modern-day challenges in any of the following themes: drinking, agriculture, urban area, ecosystem, 
energy, recreation, etc. Although, climatic change, inhabitants increase and, more recently, broad biofuel production put enormous pressure on the limited available water in a growing number of regions of the globe (Naim Haie 2011). Of the $37 \mathrm{MKm}^{3}$ of freshwater estimated to be present on the earth, about $22 \%$ exists as groundwater, which constitutes about $97 \%$ of all liquid freshwater potentially available for human use (Foster 1998). Owing to the importance of water, the United Nations has proclaimed the years of 2005-2015 as the international decade for action on "water for life" (UN 2004).

It is a well-known fact that potable safe water is absolutely essential for healthy living. Groundwater is a preferred source of human water supply. It is estimated that approximately one-third of the world's population uses groundwater for drinking purposes (UNEP 1999). For most rural and small communities, groundwater is still the only source of drinking water, because the government water supply does not reach to more than two-thirds of the population (Sharma et al. 2012). In Asia alone, about one billion people are directly dependent upon this resource (Sivasankar and Gomathi 2009). The groundwater resources play a very significant role in meeting the ever increasing demands of the agriculture, industry, and domestic sectors (Saleem 2007). Millions of hand pumps and profound tube wells have been introduced all over India since most recent few decades (1970s) to give safe water rather than microbes influenced water. However, groundwaters have some dissolved chemical constituents, which may be unacceptable due to their chronic health effects, taste, and esthetic reasons (Sankararamakrishnan et al. 2008).

Agriculture is a dominant sector in the economic development of India, as it is the source of sustenance for the majority of the population and contributes $46 \%$ of the gross national product (Kumarasamy et al. 2011). Irrigation is necessary for agricultural production in infertile and semiarid regions where rainfall is not sufficient to uphold crop growth. Irrigated agriculture consumes $60-80 \%$ of the total water usage and contributes nearly $38 \%$ of the global food production.

Understanding the aquifer hydraulic properties and hydrochemical characteristics of water is crucial for groundwater planning and management in the study area. In general, the motion of groundwater along its flow paths below the ground surface increases the concentration of the chemical species (Kortatsi 2007). Hence, the groundwater chemistry could reveal important information about the geological history of the aquifers (Elkrail et al. 2004). Groundwater chemistry, in turn, depends on a number of factors, such as general geology, degree of chemical weathering of various rock types, quality of recharge water, and inputs from sources other than water-rock interaction.
Such factors and their interactions result in a complex groundwater quality (Guler and Thyne 2004).

In this work, physical, hydrogeological, and hydrochemical data from the groundwater system will be integrated and used to determine the main factors which influence the chemistry of groundwater in the Amaravathi River basin area. There is no systematic and scientifically documented evidence of the chemical quality of the suitability of groundwater for domestic and agricultural purpose in this basin. Hence, this paper highlights the ionic and temporal variations in the groundwater quality and to evaluate the suitability of groundwater for drinking and irrigation purpose for a sustainable agriculture and basic human needs.

\section{Study area description}

\section{Location}

Amaravathi River ascends from Naimakad at a height of $2300 \mathrm{~m}$ above mean sea level in the Western Ghats in the Idukki region of Kerala state. It streams toward upper east lastly converges with the waterway Cauvery on its right bank. Amaravathi River lies between north latitudes $11.20^{\circ}$ and $12.00^{\circ}$ and east longitudes $77.28^{\circ}$ and $78.50^{\circ}$ at Karur district. The total course of the river is $282 \mathrm{~km}$ and covers a total area of $8280 \mathrm{Km}^{2}$ mainly constituting five districts namely Tirupur, Coimbatore, Erode, Dindigul, and Karur in the state Tamil nadu. Amaravathi is a tributary of Shanmuganadhi, Nankanchi, and Kodaganar Rivers, which join at 60,40 , and $20 \mathrm{~km}$ upstream of Karur town, respectively. Amaravathi enters into Karur district near Aravakurichi and merges with river Cauvery near Kattali village, and the flow in the river is seasonal from late October to early February.

\section{Drainage}

Major part of Karur district is drained by Cauvery River. Amaravathi, Kodavanar, and Nanganji are the important rivers draining the western part of the district and the river Pungar drains in the eastern part of the district. The drainage pattern, in general, is dendritic. All the rivers are seasonal and carry substantial flows during the monsoon period.

\section{Geomorphology and hydrogeology}

The entire area of the district is a pediplain. The Rangamalai hills and Kadavur hills occurring in the southern side of the district constitute the remnants of the much denuded Eastern Ghats and rise to the heights of over $1031 \mathrm{~m}$ above mean sea level. There are numerous small residual hills represented by Ayyarmalai, Thanthonimalai, and Velayuthampalayam 
hills. The general elevation of the area is ranging between 100 and $200 \mathrm{~m}$ above mean sea level. The prominent geomorphic units identified in the district are structural hilly, pediments, shallow pediments, buried pediments, and alluvial plain. Karur district is underlain entirely by Archaean Crystalline formations with recent alluvial deposits occurring along the river and stream courses. The hard consolidated crystalline rocks of Archaean age represent weathered, fissured, and fractured formations of gneisses, granites, charnockites, and other associated rocks. Groundwater occurs under phreatic conditions, and the maximum saturated thickness of the aquifer in hard rock formation varies from 15 to $35 \mathrm{~m}$ depending upon the topographic conditions. The thickness of alluvial deposit is estimated to be around 10-12 m. The aquifer parameters for the formation hard rock and alluvium are furnished in Table 1.

\section{Soil and vegetation}

Red soil is the predominant one covering a major part of the district followed by thin red soil and red loam. The red soil is predominantly seen in Kadavur, Kulithalai, Krishnarayapuram, Thanthoni, and Thogamalai blocks. The thin red soils are seen in Aravakurichi and K. Paramathy blocks. A major portion of the Karur block is covered by red loam. The major crops under cultivation in this area are paddy $(16.30 \%)$, groundnut $(6.90 \%)$, sugar cane $(6.40 \%)$, jowar $(22.60 \%)$, and banana $(5.30 \%)$. Total geographical area is 289,557 ha of which area utilized for cultivation is 114,554 ha, 37,264 ha land put into non-agricultural uses, and remaining in other activities (Table 2).

\section{Irrigation practices}

The data available indicate that an area of about 54,709 ha, which is about 18.89 percent of the total geographical area of the district, is under irrigated agriculture.

Dug wells are the major source of water for irrigation in the district, accounting for about $59.97 \%$ of the total area irrigated in the district. Tube wells account for about $9.48 \%$ of the total area irrigated in the district. On the net area irrigation, the canal irrigates only $29.45 \%$ area. The area irrigated under the tank is $1.10 \%$.

\section{Rainfall and climate}

Amaravathi River basin has four distinct seasons, namely southwest monsoon from June to early September,
Table 2 The nine-fold land use/land-cover statistics for the district (CGWB 2008)

\begin{tabular}{llr}
\hline S. No. & Classification & Area (Ha) \\
\hline 1 & Forests & 6187 \\
2 & Barren and uncultivable lands & 2901 \\
3 & Land put to non-agricultural uses & 37,264 \\
4 & Cultivable waste & 67,831 \\
5 & Permanent pastures and other grazing lands & 10,801 \\
6 & Groves not included in the area sown & 1278 \\
7 & Current fallows & 4774 \\
8 & Other fallow lands & 46,802 \\
9 & Net area sown & 111,719 \\
Total & & 289,557 \\
\hline
\end{tabular}

northeast monsoon from October to December, winter season from January to February, and summer season from March to May. The district receives the rain under the influence of both southwest and northeast monsoons. The northeast monsoon chiefly contributes to the rainfall in the district. Most of the precipitation occurs in the form of cyclonic storms caused due to the depressions in the Bay of Bengal. The southwest monsoon rainfall is highly erratic and summer rains are negligible. The normal annual rainfall over the district from 1901-2011 varies from about 620 to $745 \mathrm{~mm}$, and in 2012, it was $527.6 \mathrm{~mm}$, much less than the normal average of $652.20 \mathrm{~mm}$ (Renganathan 2014), and it is the minimum around Aravakurichi $(622.7 \mathrm{~mm})$ in the western part of the district. It gradually increases toward eastwards and attains a maximum around Kulithalai (744.6 mm). The district enjoys a tropical climate, and the relative humidities are generally between 40 and $80 \%$. The mean maximum temperature ranges from 26.7 to $38.56{ }^{\circ} \mathrm{C}$, and the mean minimum temperature ranges from 18.7 to $29.3^{\circ} \mathrm{C}$. The daytime heat is tyrannical and the temperature is as high as $43.9^{\circ} \mathrm{C}$. The lowest temperature recorded is of the order of $13.9{ }^{\circ} \mathrm{C}$ (CGWB 2008).

\section{Materials and methods}

Groundwater samples were collected from twenty-four deep bore and hand pumps during August (2012), November (2012), and February (2013), representing the pre-monsoon, monsoon, and post-monsoon seasons, respectively. Hand pumps and bore wells for sampling were selected on the basis of industrial unit as well as
Table 1 Range of aquifer parameters

\begin{tabular}{lllll}
\hline Formation & Specific yield $\%$ & Transmissivity $\mathrm{m}^{2} /$ day & Permeability $\mathrm{m} /$ day & Yield in LPS \\
\hline Alluvium & 6.8 & $45-205$ & $2-4.5$ & $8.3-16.66$ \\
Hard rock & $0.7-2.3$ & $28-75$ & $5-9$ & $1.66-2.5$ \\
\hline
\end{tabular}


different land use patterns. The locations of sampling points are shown in Fig. 1. High-density polyethylene bottles were used for sample collection. The samples were filled up to the brim and were immediately sealed to avoid exposure to air and were labeled systematically. The labeled samples were analyzed in the laboratory for various physico-chemical parameters. During sample collection (handling and preservation), standard procedures recommended by the American Public Health Association (APHA 2005) were followed to ensure data quality and consistency.

The $\mathrm{pH}$ and electrical conductivity (EC) were measured in situ by using water quality multi-parameter probe (Elico PE 138), and the major ions were analyzed using the standard methods suggested by the American Public Health Association (APHA 2005). Among the analyzed ions, sodium $\left(\mathrm{Na}^{+}\right)$and potassium $\left(\mathrm{K}^{+}\right)$were determined by using Systronics Flame photometer 128. Total hardness (TH) as $\mathrm{CaCO}_{3}$, calcium $\left(\mathrm{Ca}^{2+}\right)$, magnesium $\left(\mathrm{Mg}^{2+}\right)$, bicarbonate $\left(\mathrm{HCO}_{3}{ }^{-}\right)$, and chloride $\left(\mathrm{Cl}^{-}\right)$were analyzed by volumetric methods, and sulfates $\left(\mathrm{SO}_{4}{ }^{2-}\right)$ were estimated by using the spectrophotometer. Fluoride ion was determined by Ion selective electrode (Thermo scientific Orion
4 star). Nitrate and phosphate were determined by brucine and stannous chloride method using spectrophotometer. The accuracy of the results was checked by calculating the ionic balance errors and it was generally within $\pm 5 \%$. The hydrogeochemical facies (Piper trilinear diagram) and the Wilcox plot were plotted using the AquaChem 4.0 software. The correlation coefficient is generally used to measure and establish the relationship between two variables. The correlation coefficient matrix is obtained by using $\mathrm{R}$ environment software for windows version 2.15.2.

The suitability of groundwater for agricultural and domestic purposes was evaluated by comparing the values of different water quality parameters with those of the World Health Organization (WHO 2005) and Bureau of Indian standards (BIS 2003) guidelines values for drinking water. To assess the suitability of groundwater for irrigation uses, the following hydrochemical parameters were computed by the equations:

$$
\mathrm{SAR}=\frac{\mathrm{Na}^{+}}{\sqrt{\left(\mathrm{Ca}^{2+}+\mathrm{Mg}^{2+}\right) / 2}}
$$

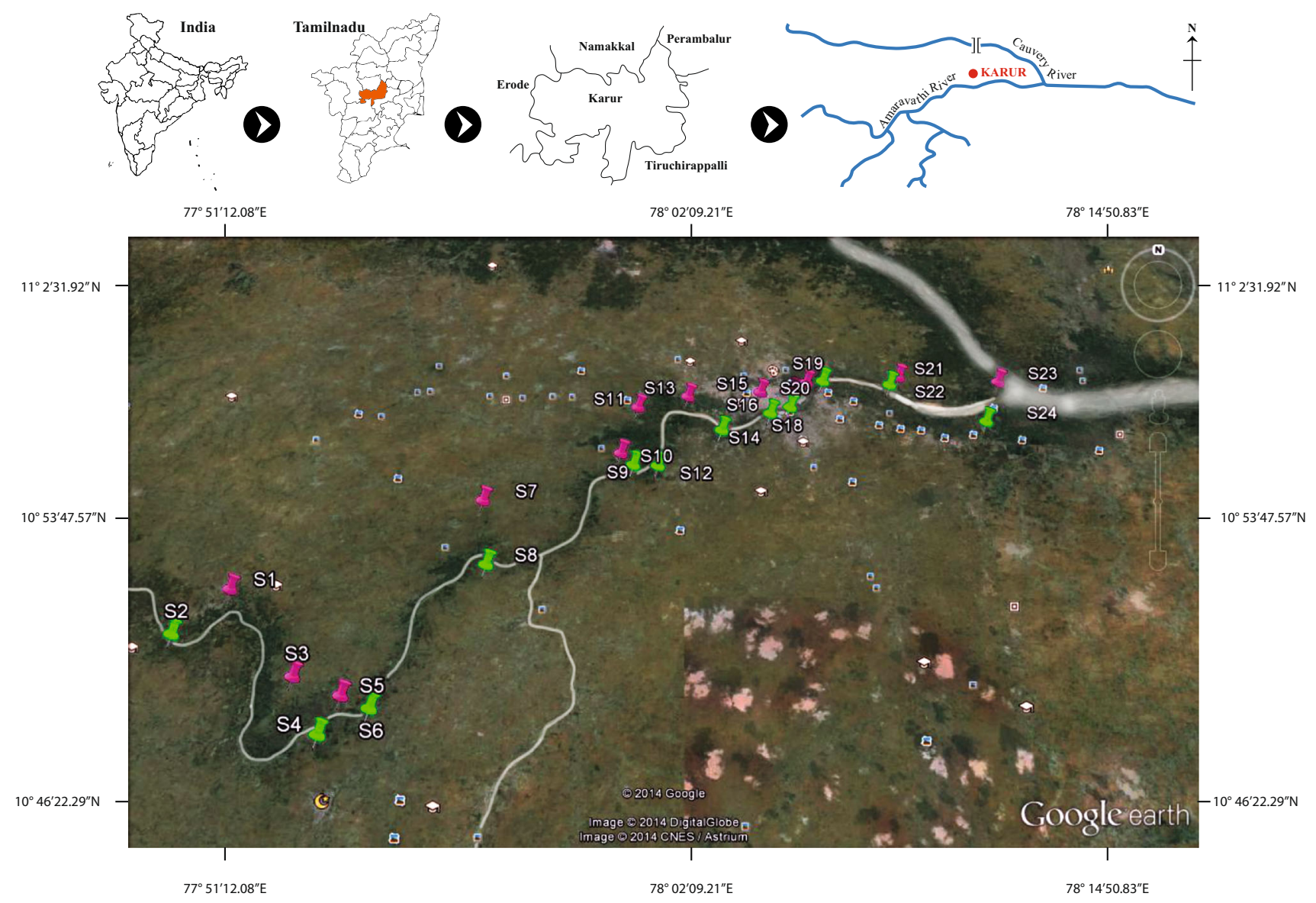

Fig. 1 Location map of the Amaravathi River basin showing sampling sites 


$$
\begin{aligned}
& \% \mathrm{Na}=\frac{\left(\mathrm{Na}^{+}+\mathrm{K}^{+}\right) \times 100}{\left(\mathrm{Ca}^{2+}+\mathrm{Mg}^{2+}+\mathrm{Na}^{+}+\mathrm{K}^{+}\right)} \\
& \mathrm{PI}=\frac{\left(\mathrm{Na}^{+}+\sqrt{\mathrm{HCO}_{3}^{-}}\right)}{\left(\mathrm{Ca}^{2+}+\mathrm{Mg}^{2+}+\mathrm{Na}^{+}\right)} \times 100 \\
& \mathrm{KR}=\frac{\mathrm{Na}^{+}}{\left(\mathrm{Ca}^{2+}+\mathrm{Mg}^{2+}\right)} \\
& \mathrm{MH}=\frac{\mathrm{Mg}^{2+} \times 100}{\left(\mathrm{Ca}^{2+}+\mathrm{Mg}^{2+}\right)} \\
& \mathrm{CAI}-\mathrm{I}=\frac{\left(\mathrm{Cl}^{-}-\left(\mathrm{Na}^{+}+\mathrm{K}^{+}\right)\right)}{\mathrm{Cl}^{-}} \\
& \mathrm{CAI}-\mathrm{II}^{-} \frac{\left(\mathrm{Cl}^{-}-\left(\mathrm{Na}^{+}+\mathrm{K}^{+}\right)\right)}{\left(\mathrm{SO}_{4}^{2-}+\mathrm{HCO}_{3}^{-}+\mathrm{CO}_{3}^{2-}+\mathrm{NO}_{3}^{-}\right)} \\
& \mathrm{RSC}=\left(\mathrm{CO}_{3}^{2-}+\mathrm{HCO}_{3}^{-}\right)-\left(\mathrm{Ca}^{2+}+\mathrm{Mg}^{2+}\right) \\
& \mathrm{PS}=\mathrm{Cl}^{-}+\left(\mathrm{SO}_{4}^{2-} / 2\right) \\
& \mathrm{GR}-\mathrm{I}=\frac{\mathrm{Cl}^{-}}{\left(\mathrm{Cl}^{-}+\mathrm{HCO}_{3}^{-}\right)} \\
& \mathrm{GR}-\mathrm{II}=\frac{\left(\mathrm{Na}^{+}+\mathrm{K}^{+}\right)}{\left(\mathrm{Na}^{+}+\mathrm{K}^{+}+\mathrm{Ca}^{2+}\right)}
\end{aligned}
$$

All the ionic concentrations in the above equations are expressed in meq/L, while percent sodium and PI in \%.

\section{Results and discussion}

\section{Hydrogeochemistry}

The physico-chemical characteristics of the groundwater samples of the Amaravathi River basin are given in Table 3 with descriptive statistical measures such as mean, minimum, maximum, and standard deviation values of various water quality parameters investigated along with the standards of the World Health Organization (WHO 2005) and Bureau of Indian standards (BIS 2003).

\section{pH}

The negative logarithm of hydrogen ion concentration is a numerical expression which denotes the degree to which water is acidic or alkaline in nature. The lower $\mathrm{pH}$ values have a tendency to make water corrosive, and higher $\mathrm{pH}$ value leads to taste grievance and harmful impact on the eyes and skin (Ravikumar et al. 2013). $\mathrm{pH}$ value in groundwater samples ranging from 7.29 to $8.17,7.33-8.45$, and 6.29-7.20 during pre-monsoon, monsoon, and post-monsoon seasons, respectively, indicates the alkaline nature and slightly acidic in post-monsoon season. All the values are well within the permissible limits prescribed by WHO and BIS.

\section{Electrical conductivity}

Electrical conductivity is used as an index to represent the available total concentration of soluble salts in water and is a direct function of its total dissolved solids (Gupta et al. 2008). The mean electrical conductivity of the groundwater samples was $3081 \mu \mathrm{S} / \mathrm{cm}$ (pre-monsoon), $3042 \mu \mathrm{S} / \mathrm{cm}$ (monsoon), and $3176 \mu \mathrm{S} / \mathrm{cm}$ (post-monsoon). The classification of electrical conductivity in groundwater is shown in Table 4. According to Langenegger (1990) classification, the majority of the samples falls under saline category. In general, EC depends upon temperature, concentration, and types of ions present (Hem 1985). Relatively higher EC values were recorded in the study area indicating the enrichments of salts in groundwater; $\mathrm{pH}$ may also increase the dissolution process which ultimately increases the $\mathrm{EC}$ value.

\section{Total dissolved solids}

Total dissolved solids indicate the various types of minerals present in water in dissolved form consisting of calcium, magnesium, sodium, potassium, carbonates, bicarbonates, chlorides, sulfate, phosphate, silica, iron, and small amounts of organic matters (Gnanachandrasamy et al. 2014; Ravikumar et al. 2013). TDS in the study area varies from 817 to $4340 \mathrm{mg} / \mathrm{L}$ (pre-monsoon), 915 to $4243 \mathrm{mg} / \mathrm{L}$ (monsoon), and 1094 to $4346 \mathrm{mg} / \mathrm{L}$ (postmonsoon). Davis and Wiest (1966) proposed four classes of water based on TDS for drinking and irrigation purposes (Table 5). None of the samples fall under "desirable for drinking" category, while $79 \%$ in pre-monsoon, $83 \%$ in monsoon, and $79 \%$ in post-monsoon seasons are suitable for irrigation, and the remaining are unfit for drinking and irrigation purposes.

\section{Total hardness}

Total hardness of water is a measure of dissolved $\mathrm{Ca}^{2+}$ and $\mathrm{Mg}^{2+}$ content expressed as $\mathrm{CaCO}_{3}$, which is also a reflection of soap-neutralizing power ( $\mathrm{Li}$ et al. 2013). Water can be classified into four categories by Sawyer and McCarthy (1967): soft $(<75 \mathrm{mg} / \mathrm{L})$, moderately hard $(75-150 \mathrm{mg} / \mathrm{L})$, hard $(150-300 \mathrm{mg} / \mathrm{L})$, and very hard ( $>300 \mathrm{mg} / \mathrm{L}$ ) based on the total hardness (Table 6). The results in Table 3 show that groundwater in the present study ranged from 206 to $1060 \mathrm{mg} / \mathrm{L}$ (pre-monsoon), 302-917 mg/L (monsoon), and 275-1020 mg/L (postmonsoon). According to the classification, none of the samples belong to soft and moderately hard; $8.30 \%$ (premonsoon) and $4.16 \%$ (post-monsoon) belong to hard type; and remaining $91.70 \%$ samples in pre-monsoon, $100 \%$ samples in monsoon, and $95.84 \%$ in post-monsoon 
Table 3 Descriptive statistics of groundwater quality of Amaravathi River basin

\begin{tabular}{|c|c|c|c|c|c|c|c|c|}
\hline Parameters & WHO limit & BIS limit & Seasons & No. of samples & Mean & Minimum & Maximum & Standard deviation \\
\hline \multirow[t]{3}{*}{$\mathrm{pH}$} & \multirow[t]{3}{*}{$7.0-8.5$} & \multirow[t]{3}{*}{$6.5-8.5$} & Pre-monsoon & 24 & 7.72 & 7.29 & 8.17 & 0.27 \\
\hline & & & Monsoon & 24 & 7.93 & 7.33 & 8.45 & 0.33 \\
\hline & & & Post-monsoon & 24 & 6.77 & 6.29 & 7.2 & 0.27 \\
\hline \multirow[t]{3}{*}{$\mathrm{EC}, \mu \mathrm{S} / \mathrm{cm}$} & \multirow[t]{3}{*}{$1000-2000$} & \multirow[t]{3}{*}{$750-2250$} & Pre-monsoon & 24 & 3081 & 1178 & 6263 & 1505 \\
\hline & & & Monsoon & 24 & 3042 & 1320 & 6123 & 1406 \\
\hline & & & Post-monsoon & 24 & 3176 & 1579 & 6270 & 1425 \\
\hline \multirow[t]{3}{*}{ TDS, mg/L } & \multirow[t]{3}{*}{500} & \multirow[t]{3}{*}{500} & Pre-monsoon & 24 & 2137 & 817 & 4340 & 1042 \\
\hline & & & Monsoon & 24 & 2108 & 915 & 4243 & 974 \\
\hline & & & Post-monsoon & 24 & 2201 & 1094 & 4346 & 990 \\
\hline \multirow[t]{3}{*}{$\mathrm{TH}, \mathrm{mg} / \mathrm{L}$} & \multirow[t]{3}{*}{300} & \multirow[t]{3}{*}{300} & Pre-monsoon & 24 & 545 & 206 & 1060 & 228 \\
\hline & & & Monsoon & 24 & 564 & 302 & 917 & 199 \\
\hline & & & Post-monsoon & 24 & 569 & 275 & 1020 & 218 \\
\hline \multirow[t]{3}{*}{$\mathrm{Ca}^{2+}, \mathrm{meq} / \mathrm{L}$} & \multirow[t]{3}{*}{3.75} & \multirow[t]{3}{*}{3.75} & Pre-monsoon & 24 & 9.44 & 2.6 & 21.65 & 5.19 \\
\hline & & & Monsoon & 24 & 9.06 & 3.8 & 20.15 & 4.13 \\
\hline & & & Post-monsoon & 24 & 10.13 & 3.8 & 23.15 & 5.21 \\
\hline \multirow[t]{3}{*}{$\mathrm{Mg}^{2+}, \mathrm{meq} / \mathrm{L}$} & \multirow[t]{3}{*}{4.165} & \multirow[t]{3}{*}{2.499} & Pre-monsoon & 24 & 8.14 & 2.5 & 22.5 & 5.57 \\
\hline & & & Monsoon & 24 & 8.33 & 2.83 & 18.91 & 5.50 \\
\hline & & & Post-monsoon & 24 & 7.93 & 2.75 & 19.58 & 4.40 \\
\hline \multirow[t]{3}{*}{$\mathrm{Na}^{+}$, meq $/ \mathrm{L}$} & \multirow[t]{3}{*}{8.696} & \multirow[t]{3}{*}{8.696} & Pre-monsoon & 24 & 15.01 & 2.26 & 39.61 & 11.07 \\
\hline & & & Monsoon & 24 & 15.0 & 2.54 & 36.68 & 10.52 \\
\hline & & & Post-monsoon & 24 & 15.29 & 3.44 & 41.77 & 10.92 \\
\hline \multirow[t]{3}{*}{$\mathrm{K}^{+}$, meq $/ \mathrm{L}$} & \multirow[t]{3}{*}{0.307} & 0.307 & Pre-monsoon & 24 & 0.44 & 0.02 & 1.49 & 0.42 \\
\hline & & & Monsoon & 24 & 0.45 & 0.09 & 1.43 & 0.41 \\
\hline & & & Post-monsoon & 24 & 0.46 & 0.1 & 1.47 & 0.45 \\
\hline $\mathrm{HCO}_{3}{ }^{-}, \mathrm{meq} / \mathrm{L}$ & 1.639 & 1.639 & Pre-monsoon & 24 & 6.95 & 3.86 & 11.09 & 1.73 \\
\hline & & & Monsoon & 24 & 7.53 & 4.47 & 12.39 & 1.65 \\
\hline & & & Post-monsoon & 24 & 7.95 & 3.96 & 12.26 & 1.93 \\
\hline $\mathrm{Cl}^{-}, \mathrm{meq} / \mathrm{L}$ & 5.634 & 7.042 & Pre-monsoon & 24 & 22.31 & 3.6 & 64.78 & 18.74 \\
\hline & & & Monsoon & 24 & 21.35 & 4.5 & 61.69 & 17.37 \\
\hline & & & Post-monsoon & 24 & 22.03 & 4.98 & 62.87 & 17.47 \\
\hline $\mathrm{F}^{-}, \mathrm{meq} / \mathrm{L}$ & 0.052 & 0.052 & Pre-monsoon & 24 & 0.049 & 0.010 & 0.215 & 0.042 \\
\hline & & & Monsoon & 24 & 0.045 & 0.005 & 0.210 & 0.042 \\
\hline & & & Post-monsoon & 24 & 0.047 & 0.010 & 0.200 & 0.038 \\
\hline $\mathrm{SO}_{4}^{2-}, \mathrm{meq} / \mathrm{L}$ & 4.166 & 4.166 & Pre-monsoon & 24 & 4.06 & 0.66 & 7.27 & 1.83 \\
\hline & & & Monsoon & 24 & 4.74 & 1.64 & 8.04 & 1.79 \\
\hline & & & Post-monsoon & 24 & 4.67 & 1.54 & 8.75 & 1.88 \\
\hline $\mathrm{NO}_{3}{ }^{-}, \mathrm{meq} / \mathrm{L}$ & 3.214 & 3.214 & Pre-monsoon & 24 & 0.014 & 0.000 & 0.035 & 0.011 \\
\hline & & & Monsoon & 24 & 0.076 & 0.026 & 0.129 & 0.028 \\
\hline & & & Post-monsoon & 24 & 0.075 & 0.024 & 0.141 & 0.030 \\
\hline $\mathrm{PO}_{4}{ }^{3-}, \mathrm{meq} / \mathrm{L}$ & 0.032 & 0.032 & Pre-monsoon & 24 & 0.003 & 0.001 & 0.020 & 0.003 \\
\hline & & & Monsoon & 24 & 0.004 & 0.002 & 0.009 & 0.002 \\
\hline & & & Post-monsoon & 24 & 0.002 & 0.001 & 0.008 & 0.001 \\
\hline
\end{tabular}

comprises very hard water. From the results, groundwater in the study area is hard to very hard type. The long-term usage of very high hard water causes health problem such as prenatal mortality, cardiovascular disorders, urolithiasis, anencephaly, and some types of cancer (Srinivas et al. 2013; Agarwal and Jagetai 1997). 
Table 4 Classification of groundwater based on electrical conductivity (Langenegger 1990)

Table 5 Water quality classification based on TDS (Davis and Wiest 1966)

\begin{tabular}{lllll}
\hline Electrical conductivity $(\mu \mathrm{S} / \mathrm{cm})$ & Category & \multicolumn{4}{l}{ Groundwater samples } \\
\cline { 3 - 5 } & & Pre-monsoon & Monsoon & Post-monsoon \\
\hline $0-333$ & Excellent & - & - & - \\
$333-500$ & Good & - & - & - \\
$500-1100$ & Permissible & - & - & - \\
$1100-1500$ & Brackish & 3 & 1 & - \\
$1500-10,000$ & Saline & 21 & 23 & 24 \\
\hline
\end{tabular}

\begin{tabular}{lllll}
\hline TDS $(\mathrm{mg} / \mathrm{L})$ & Water quality & \multicolumn{3}{l}{ Percentage of samples } \\
\cline { 3 - 5 } & & Pre-monsoon & Monsoon & Post-monsoon \\
\hline$<500$ & Desirable for drinking & - & - & - \\
$500-1000$ & Permissible for drinking & 4 & 4 & - \\
$<3000$ & Useful for irrigation & 79 & 83 & 79 \\
$>3000$ & Unfit for drinking and irrigation & 21 & 17 & 21 \\
\hline
\end{tabular}

\section{Calcium and magnesium}

Calcium and magnesium are the most abundant elements in groundwater, which exist mainly as bicarbonates, and less significant in the form of sulfate and chloride (Sarath Prasanth et al. 2012). The concentration of $\mathrm{Ca}^{2+}$ ion ranges from 2.6 to $21.65 \mathrm{meq} / \mathrm{L}, 3.8-20.15 \mathrm{meq} / \mathrm{L}$, and $3.8-23.15 \mathrm{meq} / \mathrm{L}$ for pre-monsoon, monsoon, and postmonsoon seasons, respectively. The reason for the high concentration of $\mathrm{Ca}^{+}$in groundwater is attributed by carbonate or silicate weathering. $\mathrm{Mg}^{2+}$ ion concentration in the study area ranges from 2.5 to $22.5 \mathrm{meq} / \mathrm{L}$ (premonsoon), $\quad 2.83-18.91 \mathrm{meq} / \mathrm{L} \quad$ (monsoon), and 2.75-19.58 meq/L (post-monsoon), and high concentration of $\mathrm{Mg}^{2+}$ is due to the leaching process of dolomites, limestones, and gypsum; similar results are achieved by Tay (2012). At the same time, the reverse cationic exchange takes place with sodium reducing the concentration of $\mathrm{Ca}^{2+}$ and $\mathrm{Mg}^{2+}$ ions (Thomson Jacob et al. 1999). About $75 \%$ of samples in pre-monsoon and monsoon, and $91.6 \%$ of samples in the post-monsoon seasons exceed the permissible limit specified by WHO (2005) and BIS (2003).

\section{Sodium and potassium}

Sodium along with chloride is often used to identify the proper mechanisms for acquiring salinity and saline intrusion problem in semiarid regions (Jalali 2006; Dixon and Chiswell 1992). The analytical results show that the concentration of $\mathrm{Na}^{+}$in groundwater samples in pre-monsoon ranges from 2.26 to $39.61 \mathrm{meq} / \mathrm{L}$, while in monsoon season, the minimum value is $2.54 \mathrm{meq} / \mathrm{L}$ and maximum value is $36.68 \mathrm{meq} / \mathrm{L}$, and in post-monsoon, it ranged from 3.44 to $41.77 \mathrm{meq} / \mathrm{L}$. High concentration of $\mathrm{Na}^{+}$and $\mathrm{K}^{+}$is supplied from the weathering of $\mathrm{Na}^{+}$and $\mathrm{K}^{+}$feldspar (Kim et al. 2005; Zhang et al. 1995) with carbonic acid by the following reactions.

$$
\begin{aligned}
& 2 \mathrm{NaAlSi}_{3} \mathrm{O}_{8}+2 \mathrm{H}_{2} \mathrm{CO}_{3}+9 \mathrm{H}_{2} \mathrm{O} \\
& \quad \rightarrow \mathrm{Al}_{2} \mathrm{Si}_{2} \mathrm{O}_{5}(\mathrm{OH})_{4}+2 \mathrm{HCO}_{3}+2 \mathrm{Na}+4 \mathrm{H}_{4} \mathrm{SiO}_{4}
\end{aligned}
$$

$$
\begin{aligned}
& 2 \mathrm{KAlSi}_{3} \mathrm{O}_{8}+2 \mathrm{H}_{2} \mathrm{CO}_{3}+9 \mathrm{H}_{2} \mathrm{O} \\
& \quad \rightarrow \mathrm{Al}_{2} \mathrm{Si}_{2} \mathrm{O}_{5}(\mathrm{OH})_{4}+2 \mathrm{HCO}_{3}+2 \mathrm{~K}+4 \mathrm{H}_{4} \mathrm{SiO}_{4}
\end{aligned}
$$

\begin{tabular}{|c|c|c|c|c|c|}
\hline \multirow{2}{*}{ Total hardness as $\mathrm{CaCO}_{3}(\mathrm{mg} / \mathrm{L})$} & \multirow[t]{2}{*}{ Water type } & \multirow[t]{2}{*}{ Range $(\mathrm{mg} / \mathrm{L})$} & \multicolumn{3}{|c|}{ Percentage of samples } \\
\hline & & & Pre-monsoon & Monsoon & Post-monsoon \\
\hline$<75$ & Soft & - & - & - & - \\
\hline $75-150$ & Moderately hard & - & - & - & - \\
\hline $150-300$ & Hard & 206-292 & 8.30 & - & 4.16 \\
\hline$>300$ & Vary hard & $316-1060$ & 91.70 & 100 & 95.84 \\
\hline
\end{tabular}

Excess levels of $\mathrm{Na}^{+}$fluctuated in the process, where $\mathrm{Ca}^{2+}$ and $\mathrm{Mg}^{2+}$ ions are exchanged with $\mathrm{Na}^{+}$. The

Table 6 Categorization of groundwater based on total hardness (Sawyer and McCarthy 1967) 
maximum permissible limit for $\mathrm{Na}^{+}$in drinking water is $8.696 \mathrm{meq} / \mathrm{L}$, and it reveals that $62.50 \%$ of the samples in pre-monsoon, $66.60 \%$ in monsoon and $70.80 \%$ in post-monsoon exceed the permissible limit of WHO and BIS. From the evocative indications, the intake of high levels of $\mathrm{Na}^{+}$in groundwater may cause hypertension, arteriosclerosis, edema and kidney problems (Srinivas et al. 2013; Ramesh and Elango 2012; Raju et al. 2011). Among the cations $\left(\mathrm{Ca}^{2+}, \mathrm{Mg}^{2+}\right.$ and $\left.\mathrm{Na}^{+}\right)$, the potassium concentration remains quite low. The concentration of $\mathrm{K}^{+}$is observed between 0.02 and $1.49 \mathrm{meq} / \mathrm{L} ; 0.09$ and $1.43 \mathrm{meq} / \mathrm{L}$; and 0.1 and $1.47 \mathrm{meq} / \mathrm{L}$ for pre-monsoon, monsoon, and post-monsoon seasons, respectively. The maximum permissible limit of $\mathrm{K}^{+}$in drinking water is $0.307 \mathrm{meq} / \mathrm{L}$, and it is found that $45.80 \%$ of the samples in pre-monsoon and $37.50 \%$ in monsoon and post-monsoon exceed the limits of WHO and BIS (Table 3). The runoff from agricultural activities and industrial wastes percolate into the groundwater and thus increases the $\mathrm{K}^{+}$content (Singh et al. 2006). The silicate minerals present in the groundwater increase the concentration, but compared with $\mathrm{Na}^{+}$, the low concentration of $\mathrm{K}^{+}$is due to the more resistance of potash feldspars to chemical weathering and is fixed on clay materials.

\section{Bicarbonate}

Bicarbonates and carbonates may originate from many sources such as atmospheric $\mathrm{CO}_{2}$; solution of carbonate minerals and rocks such as calcite and dolomites; weathering of feldspar by carbonic acid; and the reaction of $\mathrm{NO}_{3}{ }^{-}$and $\mathrm{SO}_{4}{ }^{2-}$ by organic matter (Awadh and Ahmed 2013). The dissolution reaction (Kim and Kim 2013) of calcite and dolomite can be written as follows:

$\mathrm{CaCO}_{3}+\mathrm{H}_{2} \mathrm{CO}_{3} \rightarrow \mathrm{Ca}^{2+}+2 \mathrm{HCO}_{3}^{-}$

$\mathrm{CaMg}\left(\mathrm{CO}_{3}\right)_{2}+\mathrm{H}_{2} \mathrm{CO}_{3} \rightarrow \mathrm{Ca}^{2+}+\mathrm{Mg}^{2+}+4 \mathrm{HCO}_{3}^{-}$

The $\mathrm{HCO}_{3}{ }^{-}$concentration in pre-monsoon ranges from 3.86 to $11.09 \mathrm{meq} / \mathrm{L}, 4.47-12.39 \mathrm{meq} / \mathrm{L}$ in monsoon, and $3.96-12.26 \mathrm{meq} / \mathrm{L}$ in the post-monsoon season. All the samples in the study area exceeded the allowable limit of 1.64 and $3.27 \mathrm{meq} / \mathrm{L}$ according to WHO and BIS guideline value. Weathering of silicate minerals such as anorthite, $\mathrm{Na}^{+}$, and $\mathrm{K}^{+}$feldspar additionally increases the concentration of $\mathrm{HCO}_{3}{ }^{-}$in groundwater samples from the upstream of the Amaravathi River basin, and in downstream, the relatively high concentration of $\mathrm{HCO}_{3}{ }^{-}$is due to the direct mixing of municipal sewages and industrial drainage from Karur region.

\section{Chloride}

Chloride is one of the major anions to be found in water from various sources such as weathering, intrusions of salt water, leaching of sedimentary rocks and soils, windblown salt in precipitation, domestic and industrial wastes, and municipal effluents (Karanth 1987; Hem 1985). Potable water should not exceed $5.634 \mathrm{meq} / \mathrm{L}$ and $7.0425 \mathrm{meq} / \mathrm{L}$ suggested by WHO and BIS. In the study area, the concentration of $\mathrm{Cl}^{-}$ranged between 3.6 and $64.78 \mathrm{meq} / \mathrm{L}$ in pre-monsoon, from 4.5 to $61.69 \mathrm{meq} / \mathrm{L}$ in monsoon, while in post-monsoon, it ranges from 4.98 to $62.87 \mathrm{meq} / \mathrm{L}$. About $75 \%$ in both pre-monsoon and monsoon, and $83.33 \%$ in post-monsoon are not suitable for drinking purposes. The highest concentration of $\mathrm{Cl}^{-}$in water is usually taken as an index of pollution and considered as the origin of groundwater contamination (Loizidou and Kapetanios 1993). Geologically important sources of chloride are appetite, sodalite, connate water, and hot springs (Anithamary et al. 2012; Freeze and Cherry 1979). Higher concentration was observed in the downstream of Amaravathi River basin mainly due to the surface runoff from agricultural land, sewage and municipal wastes, and effluents from dyeing and bleaching industries; same observations were reported by Shin et al. (2011) and Yu and Park (2004).

\section{Fluoride}

Fluoride is estimated to be the 13th most abundant element and is widely dispersed in nature (Viswanathan et al. 2009). $\mathrm{F}^{-}$is an essential micronutrient for human health taken in small quantities $(0.5-1.0 \mathrm{mg} / \mathrm{L})$, serving to strengthen the apatite matrix of skeletal tissues and teeth (Sharma et al. 2012; Rafique et al. 2009). The $\mathrm{F}^{-}$concentration in groundwater of pre-monsoon ranges from 0.010 to $0.215 \mathrm{meq} / \mathrm{L}, 0.005-0.210 \mathrm{meq} / \mathrm{L}$ in monsoon, and $0.010-0.200 \mathrm{meq} / \mathrm{L}$ in the post-monsoon season. The World Health Organization and Bureau of Indian standard described the drinking water quality as the permissible limit for $\mathrm{F}^{-}$is $0.052 \mathrm{meq} / \mathrm{L}$, where in the study area, $29 \%$ of samples in all three seasons exceeding the guideline value. The reason behind for high value recorded in the study area was constituted of the fractured hard rock zone. Anomalous level of $\mathrm{F}^{-}$in water is widespread in the fractured hard rock zone with pegmatite veins (Viswanathan et al. 2010; Ramesam and Rajagopalan 1985). Fluorite $\left(\mathrm{CaF}_{2}\right)$ and calcite $\left(\mathrm{CaCO}_{3}\right)$ both contain $\mathrm{Ca}^{2+}$, their solubilities are interdependent, as the resultant conditions that lead to low calcite solubility can also lead to high concentration of $\mathrm{F}^{-}$in groundwater (Rafique et al. 2008; Kundu et al. 2001). Excessive intake of $\mathrm{F}^{-}$results in 
dental Fluorosis, muscle fiber degeneration, headache, skin rashes, nervousness, and depression (Meenakshi 2006).

\section{Sulfate}

Sulfate is one of the important anions present in natural water probably derived from weathering of sulfate and gypsum-bearing sedimentary rocks (Elango et al. 2003). The sulfide minerals add the soluble sulfate into the groundwater through an oxidation process (Ramesh and Vennila 2012). In the present investigation, the concentration of $\mathrm{SO}_{4}{ }^{2-}$ in pre-monsoon season varies from 0.66 to 7. $27 \mathrm{meq} / \mathrm{L}$; during monsoon, it is $1.64-8.04 \mathrm{meq} / \mathrm{L}$; and in post-monsoon season, it varied between 1.54 and $8.75 \mathrm{meq} / \mathrm{L}$. The most admirable limit for $\mathrm{SO}_{4}{ }^{2-}$ concentration in drinking water is $4.166 \mathrm{meq} / \mathrm{L}$ prescribed by BIS (2003) and WHO (2005). During pre-monsoon and postmonsoon seasons, $50 \%$ of samples exceed the guideline value, while in monsoon it is $66.66 \%$. Higher concentration of $\mathrm{SO}_{4}{ }^{2-}$ in water may cause respiratory problems and also cause corrosion of metals if water had low alkaline value (Raju et al. 2011).

\section{Nitrate and phosphate}

Nitrate and phosphate are the major plant nutrient, and its composition is related to soils, climate and atmospheric inputs, local geology, topography, and human activities related to land use (Awadh and Ahmed 2013; Sparks 2003). The guideline value for $\mathrm{NO}_{3}{ }^{-}$concentration in drinking water is $3.214 \mathrm{meq} / \mathrm{L}$ recommended by $\mathrm{WHO}$ and BIS. In three seasons, all the samples in the study area are well within the permissible limit. The limiting factor of phosphate in natural water for plant growth is approximately $0.0002 \mathrm{meq} / \mathrm{L}$. However, to accelerate the plant growth, farmers use excess phosphate pesticides which result in the contamination of surface and groundwater through runoff and affect aquatic life (Hutak 2000). In the study area, the concentration of phosphate range between 0.001 and $0.020 \mathrm{meq} / \mathrm{L}$ in pre-monsoon and from 0.002 to $0.009 \mathrm{meq} / \mathrm{L}$ in monsoon season, while in post-monsoon season, it ranges from 0.001 to $0.008 \mathrm{meq} / \mathrm{L}$.

\section{Correlation analysis}

Karl Pearson correlation matrix analysis is a useful tool in hydrogeochemical studies that can indicate the associations between individual parameters and thus revealing the overall rationality of dataset and enlightening the links between individual parameters and various controlling factors (Wang and Jiao 2012; Li et al. 2013). A correlation coefficient of $<0.5$ exhibits poor correlation, 0.5 represents the good correlation, and $>0.5$ highlights the excellent correlation (Vasanthavigar et al. 2013). The obtained result is listed in Table 7 which shows positive and negative correlation between various variables.

During pre-monsoon, monsoon, and post-monsoon seasons, high positive correlation of EC, TDS with $\mathrm{Cl}^{-}$ $(r=0.97,0.98,0.97), \mathrm{Na}^{+}(r=0.91,0.90,0.90)$, and $\mathrm{TH}$ ( $r=0.87,0.80,0.82)$ is observed, respectively. Some good correlation is also observed between $\mathrm{TH}$ and $\mathrm{Ca}^{2+}$ $(r=0.87), \mathrm{Na}^{+}$and $\mathrm{Cl}^{-}(r=0.85), \mathrm{Mg}^{2+}$ and $\mathrm{Cl}^{-}$ $(r=0.80)$, and $\mathrm{Ca}^{2+}$ and $\mathrm{Cl}^{-}(r=0.79)$ in pre-monsoon, whereas in monsoon, it is $r=0.84,0.86,0.75$, and 0.76 , respectively. While in post-monsoon, the respective $(r)$ value for the above said parameter is $r=0.87,0.82,0.73$, and 0.85 , respectively. These positive correlations indicate that $\mathrm{Na}^{+}, \mathrm{K}^{+}, \mathrm{Ca}^{2+}$, and $\mathrm{Mg}^{2+}$ ions are derived from weathering of $\mathrm{Na}^{+}, \mathrm{K}^{+}$feldspar, and dissolution of carbonate minerals. The positive relation between $\mathrm{F}^{-}$and $\mathrm{HCO}_{3}{ }^{-}(r=0.51,0.62$ and 0.48$)$ in pre-monsoon, monsoon, and post-monsoon indicates when both calcite and fluorite are in contact with water (Mamatha and Rao 2010; Rafique et al. 2008). The possible equation is

$\mathrm{CaF}_{2}+\mathrm{HCO}_{3}^{-} \rightarrow \mathrm{CaCO}_{3}+\mathrm{H}^{+}+2 \mathrm{~F}^{-}$

The negative correlation of $\mathrm{Ca}^{2+}, \mathrm{Mg}^{2+}$ with $\mathrm{Cl}^{-}$ $(r=-0.15$ and -0.19$)$ is observed in pre-monsoon, $\mathrm{Mg}^{2+}$ with $\mathrm{SO}_{4}{ }^{2-}(r=-0.01)$ and $\mathrm{HCO}_{3}{ }^{-}(r=-0.06)$ in monsoon season, and in the post-monsoon, $\mathrm{Ca}^{2+}$ and $\mathrm{Mg}^{2+}$ shows negative correlation with $\mathrm{HCO}_{3}{ }^{-}(r=-0.05$ and $-0.025)$. $\mathrm{pH}$ shows negative correlation with most of the water quality parameters.

\section{Hydrochemical facies}

Piper (1944) proposed a modified trilinear diagram for understanding the hydrogeochemical regime of the study area. The diagram consists of three distinct fields, two triangular fields, and one diamond-shaped field (Fig. 2). The left triangle indicates the percentage of cations and right designates the anions which are expressed in meq/L as a single plot. The plots on the diamond field show the similarities and differences among groundwater samples (Jafar Ahamed et al. 2013).

The triangular cationic field in pre-monsoon indicates that $71 \%$ of samples fall into no dominant type, and 16.50 and $12.50 \%$ samples are in $\mathrm{Mg}^{2+}$ and $\mathrm{Na}^{+}+\mathrm{K}^{+}$type, respectively. From the anionic triangle, $83.50 \%$ samples fall into $\mathrm{Cl}^{-}$type and the remaining are in no dominant class. Most of the samples in Zone 4 of diamond-shaped field indicate the predominance of mixed $\mathrm{Ca}^{2+}-\mathrm{Mg}^{2+}-\mathrm{Cl}^{-}$ type followed by $\mathrm{Ca}^{2+}-\mathrm{Cl}^{-}$and $\mathrm{Na}^{+}-\mathrm{Cl}^{-}$type. During monsoon season, most of the samples $(75 \%)$ are present in no dominant class followed by $12.5 \%$ each of $\mathrm{Mg}^{2+}$ and $\mathrm{Na}^{+}+\mathrm{K}^{+}$type in cationic triangle, whereas in anionic 
Table 7 Karl Pearson correlation coefficient for different water quality parameters

\begin{tabular}{|c|c|c|c|c|c|c|c|c|c|c|c|c|c|c|}
\hline Parameters & $\mathrm{pH}$ & EC & TDS & $\mathrm{TH}$ & $\mathrm{Ca}$ & $\mathrm{Mg}$ & $\mathrm{Na}$ & $\mathrm{K}$ & $\mathrm{HCO}_{3}$ & $\mathrm{Cl}$ & $\mathrm{F}$ & $\mathrm{SO}_{4}$ & $\mathrm{NO}_{3}$ & $\mathrm{PO}_{4}$ \\
\hline \multicolumn{15}{|c|}{ (a) Pre-monsoon } \\
\hline $\mathrm{pH}$ & 1.00 & -0.60 & -0.60 & -0.66 & -0.70 & -0.48 & -0.42 & -0.01 & -0.03 & -0.63 & -0.02 & -0.10 & -0.36 & 0.32 \\
\hline $\mathrm{EC}$ & & 1.00 & 1.00 & 0.87 & 0.73 & 0.75 & 0.91 & 0.13 & 0.20 & 0.97 & 0.26 & 0.27 & 0.12 & -0.34 \\
\hline TDS & & & 1.00 & 0.87 & 0.73 & 0.75 & 0.91 & 0.13 & 0.20 & 0.97 & 0.26 & 0.27 & 0.12 & -0.34 \\
\hline $\mathrm{TH}$ & & & & 1.00 & 0.87 & 0.80 & 0.63 & -0.09 & -0.12 & 0.90 & 0.06 & 0.14 & 0.10 & -0.37 \\
\hline $\mathrm{Ca}$ & & & & & 1.00 & 0.53 & 0.54 & -0.16 & -0.15 & 0.79 & 0.00 & 0.17 & 0.07 & -0.38 \\
\hline $\mathrm{Mg}$ & & & & & & 1.00 & 0.49 & -0.05 & -0.19 & 0.80 & 0.01 & 0.10 & 0.15 & -0.31 \\
\hline $\mathrm{Na}$ & & & & & & & 1.00 & 0.25 & 0.39 & 0.85 & 0.33 & 0.32 & 0.12 & -0.21 \\
\hline $\mathrm{K}$ & & & & & & & & 1.00 & 0.56 & 0.02 & 0.02 & 0.26 & 0.39 & -0.12 \\
\hline $\mathrm{HCO}_{3}$ & & & & & & & & & 1.00 & 0.02 & 0.51 & 0.10 & 0.12 & -0.20 \\
\hline $\mathrm{Cl}$ & & & & & & & & & & 1.00 & 0.14 & 0.18 & 0.10 & -0.30 \\
\hline $\mathrm{F}$ & & & & & & & & & & & 1.00 & 0.05 & -0.06 & -0.05 \\
\hline $\mathrm{SO}_{4}$ & & & & & & & & & & & & 1.00 & 0.13 & 0.00 \\
\hline $\mathrm{NO}_{3}$ & & & & & & & & & & & & & 1.00 & 0.12 \\
\hline $\mathrm{PO}_{4}$ & & & & & & & & & & & & & & 1.00 \\
\hline \multicolumn{15}{|c|}{ (b) Monsoon } \\
\hline $\mathrm{pH}$ & 1.00 & -0.74 & -0.74 & -0.72 & -0.68 & -0.78 & -0.51 & -0.04 & -0.01 & -0.78 & 0.13 & 0.02 & -0.05 & -0.39 \\
\hline $\mathrm{EC}$ & & 1.00 & 1.00 & 0.80 & 0.76 & 0.70 & 0.90 & 0.13 & 0.21 & 0.98 & 0.29 & 0.12 & -0.09 & 0.50 \\
\hline TDS & & & 1.00 & 0.80 & 0.76 & 0.70 & 0.90 & 0.13 & 0.21 & 0.98 & 0.29 & 0.12 & -0.09 & 0.50 \\
\hline $\mathrm{TH}$ & & & & 1.00 & 0.84 & 0.81 & 0.54 & -0.13 & 0.09 & 0.82 & 0.17 & 0.05 & -0.22 & 0.31 \\
\hline $\mathrm{Ca}$ & & & & & 1.00 & 0.63 & 0.50 & -0.27 & 0.03 & 0.76 & 0.12 & 0.20 & -0.31 & 0.49 \\
\hline $\mathrm{Mg}$ & & & & & & 1.00 & 0.40 & -0.08 & -0.06 & 0.75 & 0.04 & -0.01 & -0.05 & 0.26 \\
\hline $\mathrm{Na}$ & & & & & & & 1.00 & 0.25 & 0.27 & 0.86 & 0.36 & 0.12 & -0.06 & 0.46 \\
\hline $\mathrm{K}$ & & & & & & & & 1.00 & 0.35 & 0.05 & 0.00 & -0.05 & 0.41 & -0.11 \\
\hline $\mathrm{HCO}_{3}$ & & & & & & & & & 1.00 & 0.05 & 0.62 & 0.07 & 0.49 & 0.03 \\
\hline $\mathrm{Cl}$ & & & & & & & & & & 1.00 & 0.20 & 0.00 & -0.18 & 0.51 \\
\hline $\mathrm{F}$ & & & & & & & & & & & 1.00 & -0.02 & 0.31 & 0.04 \\
\hline $\mathrm{SO}_{4}$ & & & & & & & & & & & & 1.00 & 0.12 & 0.14 \\
\hline $\mathrm{NO}_{3}$ & & & & & & & & & & & & & 1.00 & -0.14 \\
\hline $\mathrm{PO}_{4}$ & & & & & & & & & & & & & & 1.00 \\
\hline \multicolumn{15}{|c|}{ (c) Post-monsoon } \\
\hline $\mathrm{pH}$ & 1.00 & -0.54 & -0.54 & -0.59 & -0.70 & -0.63 & -0.23 & -0.04 & 0.13 & -0.60 & 0.17 & -0.02 & 0.20 & 0.09 \\
\hline EC & & 1.00 & 1.00 & 0.82 & 0.82 & 0.64 & 0.90 & 0.11 & 0.27 & 0.97 & 0.25 & 0.16 & -0.20 & -0.02 \\
\hline TDS & & & 1.00 & 0.82 & 0.82 & 0.64 & 0.90 & 0.11 & 0.27 & 0.97 & 0.25 & 0.16 & -0.20 & -0.02 \\
\hline TH & & & & 1.00 & 0.87 & 0.75 & 0.57 & -0.14 & -0.01 & 0.86 & 0.12 & 0.11 & -0.14 & 0.00 \\
\hline $\mathrm{Ca}$ & & & & & 1.00 & 0.65 & 0.56 & -0.17 & -0.05 & 0.85 & 0.11 & 0.26 & -0.22 & -0.07 \\
\hline $\mathrm{Mg}$ & & & & & & 1.00 & 0.33 & -0.19 & -0.25 & 0.73 & -0.03 & 0.09 & -0.08 & -0.25 \\
\hline $\mathrm{Na}$ & & & & & & & 1.00 & 0.22 & 0.48 & 0.82 & 0.33 & 0.08 & -0.19 & 0.02 \\
\hline $\mathrm{K}$ & & & & & & & & 1.00 & 0.40 & -0.02 & 0.15 & 0.12 & -0.03 & 0.31 \\
\hline $\mathrm{HCO}_{3}$ & & & & & & & & & 1.00 & 0.09 & 0.48 & -0.12 & 0.16 & 0.52 \\
\hline $\mathrm{Cl}$ & & & & & & & & & & 1.00 & 0.15 & 0.06 & -0.23 & -0.14 \\
\hline F & & & & & & & & & & & 1.00 & 0.06 & 0.09 & 0.05 \\
\hline $\mathrm{SO}_{4}$ & & & & & & & & & & & & 1.00 & -0.07 & 0.08 \\
\hline $\mathrm{NO}_{3}$ & & & & & & & & & & & & & 1.00 & 0.32 \\
\hline $\mathrm{PO}_{4}$ & & & & & & & & & & & & & & 1.00 \\
\hline
\end{tabular}

Bold values indicate that the parameters had significant correlation from marginal to good 
triangle $83.50 \%$ samples fall into $\mathrm{Cl}^{-}$type and remaining $16.50 \%$ are in no dominant class. $\mathrm{No}_{\mathrm{HCO}_{3}}{ }^{-}$or $\mathrm{SO}_{4}{ }^{2-}$ types were identified. About $62.50 \%$ samples exhibit dominance of mixed chemical character, $\mathrm{Ca}^{2+}-\mathrm{Mg}^{2+}-\mathrm{Cl}^{-}$ type trailed by $\mathrm{Ca}^{2+}-\mathrm{Cl}^{-}$and $\mathrm{Na}^{+}-\mathrm{Cl}^{-}$type. In postmonsoon season, most of the samples $(75 \%)$ present in zone B indicates no dominant class, $16.5 \%$ is in $\mathrm{Mg}^{2+}$ type, and $8.5 \%$ samples follow $\mathrm{Na}^{+}+\mathrm{K}^{+}$type in the cationic triangular field. About $87.50 \%$ samples in the anionic triangle account for the Cl-type and further $12.50 \%$ account for no dominant class. The same observation is obtained in the diamond field compared with the monsoon season. Samples present in zones 4 and 5 indicate the dissolution of sedimentary rocks and $\mathrm{Na}^{+}$feldspar minerals, secondary evaporation and ion exchange processes which eventually increase the concentration of milliequivalent percentage of $\mathrm{Na}^{+}$and $\mathrm{Cl}^{-}$, and decrease the percentage of $\mathrm{HCO}_{3}{ }^{-}, \mathrm{SO}_{4}{ }^{2-}$, and $\mathrm{Ca}^{2+}$. The results show that mixed $\mathrm{Ca}^{2+}-\mathrm{Mg}^{2+}-\mathrm{Cl}^{-} \mathrm{t}$ is the predominant type identified and followed by $\mathrm{Ca}^{2+}-\mathrm{Cl}^{-}$and $\mathrm{Na}^{+}-\mathrm{Cl}^{-}$ type.

\section{Gibbs mechanism for groundwater evolution}

The reaction between groundwater and aquifer minerals plays a vital role in water quality, which helps to understand the genesis of groundwater (Bozdag and Gocmez 2013; Prasanna et al. 2010). The mechanism controlling the chemical composition of major dissolved salts in water and ascertained close relationships between aquifer lithology and water compositional chemistry was proposed by Gibbs (1970) through Gibbs diagram for major cations and anions. This diagram was employed to assess hydrochemical processes such as atmospheric precipitation dominance, rock weathering dominance, and evaporationcrystallization dominance by plotting the weight ratios of $\left(\mathrm{Na}^{+}+\mathrm{K}^{+}\right) /\left(\mathrm{Na}^{+}+\mathrm{Ca}^{2+}\right)$ and $\mathrm{Cl}^{-} /\left(\mathrm{Cl}^{-}+\mathrm{HCO}_{3}{ }^{-}\right)$ represented as a function of TDS (Marghade et al. 2012).

Figure $3 \mathrm{a}$ illustrates that the majority of groundwater samples in pre-monsoon, monsoon, and post-monsoon seasons fall in the evaporation-crystallization dominance and only a few samples are in rock weathering dominance by plotting $\left(\mathrm{Na}^{+}+\mathrm{K}^{+}\right) /\left(\mathrm{Na}^{+}+\mathrm{Ca}^{2+}\right)$ against TDS. Figure $3 \mathrm{~b}$ shows that $66.60 \%$ in pre-monsoon, $75 \%$ in monsoon and post-monsoon seasons have a plot in the evaporation-crystallization field. Only 33.40 \% (pre-monsoon) and $25 \%$ (monsoon and post-monsoon seasons) samples were falling in a rock weathering field, due to weathering of minerals and salt precipitation. But evaporation-crystallization is the dominant field, indicating the secondary evaporation. Groundwater evaporation is a common phenomenon in the Amaravathi River basin. When evaporation increases salinity, the concentration of $\mathrm{Na}^{+}$and $\mathrm{Cl}^{-}$contents also increases by increasing TDS. Anthropogenic activity is also responsible for evaporation due to excess usage of agricultural fertilizers and irrigation return flow, which enhance $\mathrm{Na}^{+}$and $\mathrm{Cl}^{-}$concentrations (Gupta et al. 2008).
Fig. 2 Piper trilinear diagram for groundwater samples

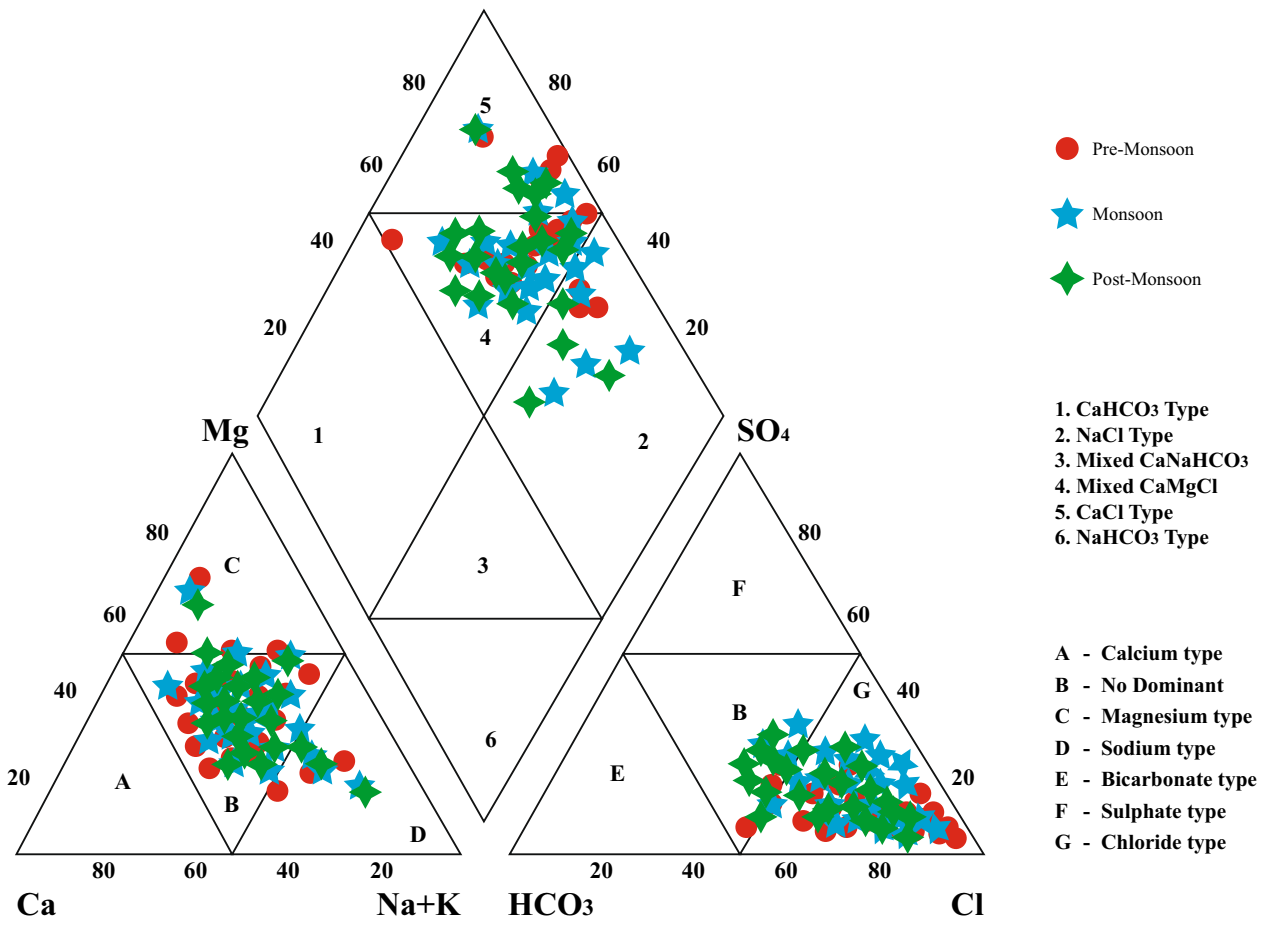




\section{Drinking water suitability}

Based on the water quality parameter results, the groundwater samples are not fit for drinking purposes with respect to the high content of TDS, TH, $\mathrm{Ca}^{2+}, \mathrm{Mg}^{2+}, \mathrm{Na}^{+}, \mathrm{Cl}^{-}$, $\mathrm{HCO}_{3}{ }^{-}$, and $\mathrm{F}^{-}$. The dominant cation trend was in the order of $\mathrm{Na}^{+}>\mathrm{Ca}^{2+}>\mathrm{Mg}^{2+}>\mathrm{K}^{+}$, and the dominant anion trend was in the order of $\mathrm{Cl}^{-}>\mathrm{HCO}_{3}{ }^{-}>-$ $\mathrm{SO}_{4}{ }^{2-}>\mathrm{NO}_{3}{ }^{-}$. The radial diagram (Fig. 4) shows the ionic trends in groundwater of the Amaravathi River basin; the same result was observed for monsoon and post-monsoon, while monsoon season has some variation due to infiltration and flow rate.

\section{Suitability of groundwater for irrigation purposes}

To determine the quality of groundwater for irrigation purposes, some hydrochemical parameters are used such as EC, salinity, sodium absorption ratio (SAR), residual sodium carbonate (RSC), percent sodium, Kelly's ratio (KR), magnesium hazard (MH), potential salinity (PS), chloro-alkaline indices (CAI I and CAI II), and permeability index (PI). Suitability of groundwater for irrigation purpose depends on the dissolved ion constituent, and one important factor which relates to plant growth with water quality is drainage. If the crop production is high, the soil is well drained even if it is highly saline water, but in poorly drained areas, the groundwater is not satisfied even with good water quality (Todd 1980; Richards 1954).

\section{Salinity hazard}

Richards (1954) classified groundwater for irrigation uses into four types according to electrical conductivity. The high EC value indicates the enrichments of salt content in water. High salinity leads to the formation of saline soils, which does not support plant growth. During pre-monsoon and monsoon seasons, 37.50 and $62.50 \%$ samples (Table 9) are in high- and very high-salinity category, while in post-monsoon, $33.70 \%$ account for high salinity and remaining fall in very high-salinity category. None of the samples are in excellent-to-medium classes, which indicate the groundwater in the study area is highly saline.

\section{Sodium absorption ratio}

Sodium hazard is a tendency of water to replace absorbed $\mathrm{Ca}^{2+}+\mathrm{Mg}^{2+}$ with $\mathrm{Na}^{+}$, which is expressed in terms of SAR. The sodium forms alkaline soils with a combination of carbonates and with chloride forms salinity. Exchangeable $\mathrm{Ca}^{2+}+\mathrm{Mg}^{2+}$ ions are replaced by $\mathrm{Na}^{+}$, which cause deflocculation and lose permeability of soils (Arveti et al. 2011; Todd 1980). The SAR value in the study area ranges from 1.039 to $15.21 \mathrm{meq} / \mathrm{L}$ for pre-monsoon, 0.855-15.39 meq/L in monsoon season, while in post-monsoon it ranges from 1.063 to $17.17 \mathrm{meq} / \mathrm{L}$ (Table 8 ). Seventyfive percent samples in pre-monsoon and $66.70 \%$ samples in monsoon and post-monsoon seasons fall in $0-6 \mathrm{meq} / \mathrm{L}$ with no problems (Table 7) on SAR and remaining in the other two categories 6-9 and $>9 \mathrm{meq} / \mathrm{L}$ having alkalinity problems.
Fig. 3 Mechanism controlling groundwater in Amaravathi River basin
Pre-Monsoon

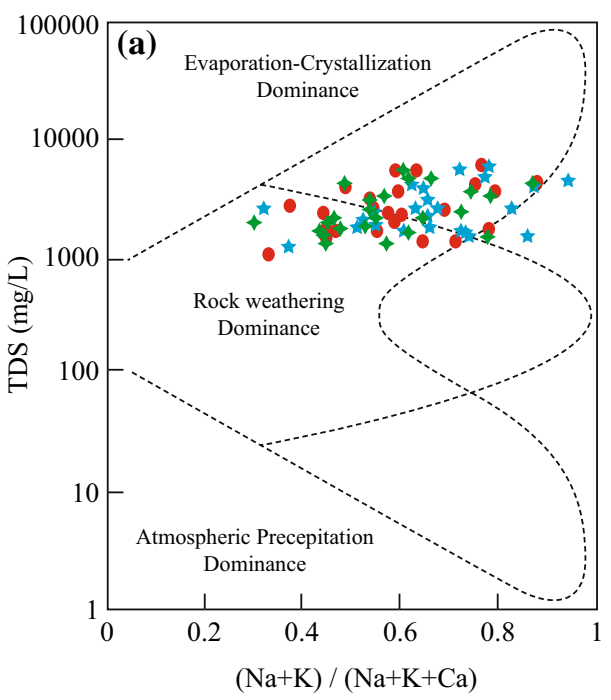

Monsoon

Post-Monsoon

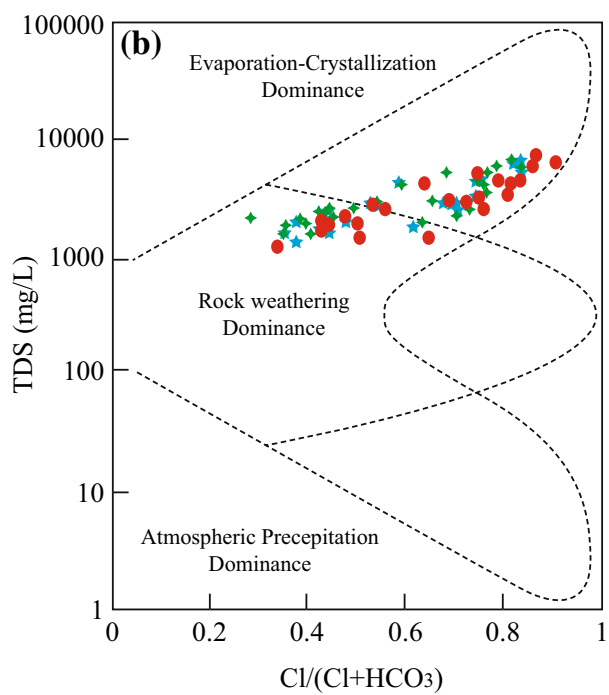


Pre-Monsoon

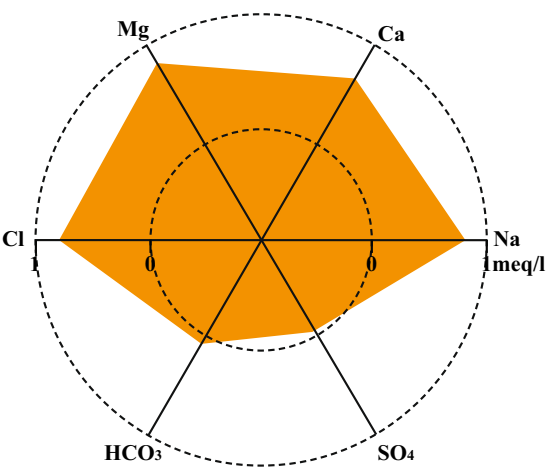

Monsoon

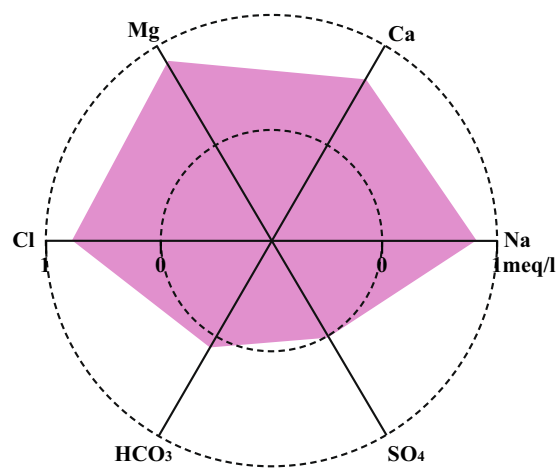

Post-Monsoon

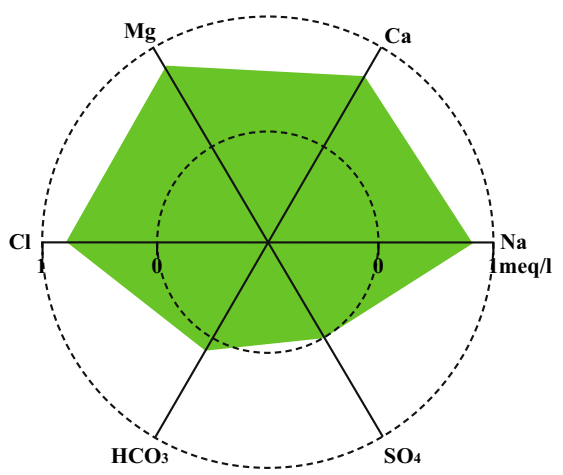

Fig. 4 Radial diagram showing major ion chemistry in groundwater of Amaravathi River basin

\section{USSL diagram}

United States salinity diagram was obtained by plotting values of salinity hazard versus alkali hazard values. The USSL (1954) diagram classifies the groundwater quality into sixteen zones to assess the degree of suitability of water for agricultural purposes. From Fig. 5, the salinity hazard $(\mathrm{C})$ can be divided into four sub-zones: $\mathrm{C} 1$ (lowsalinity hazard, $<250 \mu \mathrm{S} / \mathrm{cm}$ ), C2 (medium-salinity hazard, 250 to $750 \mu \mathrm{S} / \mathrm{cm}$ ), C3 (high-salinity hazard, $750-2250 \mu \mathrm{S} /$ $\mathrm{cm}$ ), and C4 (very high-salinity hazard, $>2250 \mu \mathrm{S} / \mathrm{cm}$ ), considering good, moderate, poor, and very poor classes, respectively. The sodium hazard ( $\mathrm{S}$ ) can be classified into four sub-zones such as S1 (low-sodium hazard, <10), S2 (medium-sodium hazard, 10-18), S3 (high-sodium hazard, 18-26), and S4 (very high-sodium hazard, >26) considering them as good, moderate, poor, and very poor classes, respectively.

It was found that $33.30 \%$ in pre-monsoon, $41.70 \%$ in monsoon, and $37.50 \%$ in post-monsoon seasons fall in the zone of C3-S1 indicating high-salinity and lowsodium hazards (Fig. 5); it can be used for irrigation in almost all types of soil with a little danger of exchangeable sodium. Of the samples, approximately $66.70 \%$ in pre-monsoon, $58.30 \%$ in monsoon, and $62.50 \%$ in postmonsoon fall in the zone of C4-S1 indicating very high salinity and low-sodium hazard, and it is not suitable for irrigation under usual conditions. It can be used only on crops that are very tolerant of salt. Extravagant solutes in groundwater water are a typical issue in semi arid regions, where water loss through evaporation is maximal (Ramesh and Elango 2012). Poor drainage allows the water table to rise close to the root zone of plants, causing accumulation of $\mathrm{Na}^{+}$salt in the soil solution through capillary rise following surface evaporation. Salt-tolerant plants/crops should be selected for high-saline regions, and the irrigation water must be applied in excess to provide considerable leaching (Singh et al. 2012) or mixed with surface water to reduce salinity.

\section{Percent sodium}

The sodium content is usually expressed in terms of percent sodium or soluble sodium, which is widely used for evaluating the suitability of water for irrigation (Wilcox 1955). Based on $\% \mathrm{Na}^{+}$, it is classified into five types; excellent, good, permissible, doubtful, and unsuitable (Table 9). The percent sodium content in groundwater varied from 15.60 to $74.99 \%$ in pre-monsoon, $10.92-76.85 \%$ in monsoon, and $14.84-78.36 \%$ in postmonsoon. In general, percent sodium should not exceed $60 \%$, and above that it was not better for better crop yields. Approximately, $87 \%$ of water samples in premonsoon and $83.30 \%$ in monsoon and post-monsoon range from excellent to permissible category, and the remaining are observed in doubtful category.

\section{Wilcox diagram}

The suitability of groundwater of the Amaravathi River basin for agricultural purposes was evaluated according to Wilcox diagram. The percent sodium values and corresponding EC values are plotted within the Wilcox diagram and are categorized into five zones, excellent to good, good to permissible, permissible to doubtful, doubtful to unsuitable, and unsuitable. Plot of analytical data on Wilcox diagram shows that no one samples fall in excellent to good category in all three seasons, although in pre-monsoon, monsoon, and post-monsoon seasons, 33.30, 25.00, and $12.50 \%$ samples, respectively, are observed in good to permissible category (Fig. 6) and only $4.20 \%$ in monsoon and post-monsoon seasons, respectively, are present in permissible to doubtful zone. In doubtful to unsuitable zone, $29.20 \%, 33.30$ and $45.80 \%$ samples fall in pre- 
Table 8 Basic statistics of groundwater for irrigation purpose

\begin{tabular}{|c|c|c|c|c|c|}
\hline Parameters & Seasons & Mean & Minimum & Maximum & Standard deviation \\
\hline \multirow[t]{3}{*}{$\mathrm{SAR}, \mathrm{meq} / \mathrm{L}$} & Pre-monsoon & 5.015 & 1.039 & 15.21 & 3.328 \\
\hline & Monsoon & 5.156 & 0.855 & 15.39 & 3.354 \\
\hline & Post-monsoon & 5.136 & 1.063 & 17.17 & 3.556 \\
\hline \multirow[t]{3}{*}{ Percent Na, \% } & Pre-monsoon & 44.05 & 15.60 & 74.99 & 13.61 \\
\hline & Monsoon & 44.78 & 10.92 & 76.85 & 14.87 \\
\hline & Post-monsoon & 43.88 & 14.84 & 78.36 & 14.26 \\
\hline \multirow[t]{3}{*}{ PI, \% } & Pre-monsoon & 53.70 & 25.46 & 80.52 & 12.65 \\
\hline & Monsoon & 54.40 & 19.31 & 82.40 & 14.18 \\
\hline & Post-monsoon & 53.36 & 24.13 & 84.36 & 13.70 \\
\hline \multirow[t]{3}{*}{$\mathrm{KR}$, meq/L } & Pre-monsoon & 0.890 & 0.172 & 2.921 & 0.605 \\
\hline & Monsoon & 0.942 & 0.114 & 3.228 & 0.680 \\
\hline & Post-monsoon & 0.913 & 0.164 & 3.530 & 0.717 \\
\hline \multirow[t]{3}{*}{$\mathrm{MH}, \mathrm{meq} / \mathrm{L}$} & Pre-monsoon & 44.86 & 23.71 & 70.88 & 14.23 \\
\hline & Monsoon & 45.48 & 29.79 & 72.39 & 10.29 \\
\hline & Post-monsoon & 43.54 & 26.58 & 65.31 & 8.754 \\
\hline \multirow[t]{3}{*}{$\mathrm{PS}, \mathrm{meq} / \mathrm{L}$} & Pre-monsoon & 12.94 & 2.317 & 49.66 & 11.76 \\
\hline & Monsoon & 10.25 & 2.138 & 28.10 & 8.846 \\
\hline & Post-monsoon & 10.76 & 2.365 & 28.51 & 8.884 \\
\hline \multirow[t]{3}{*}{$\mathrm{CAI}-\mathrm{I}, \mathrm{meq} / \mathrm{L}$} & Pre-monsoon & 0.18 & -0.39 & 0.77 & 0.32 \\
\hline & Monsoon & 0.12 & -1.21 & 0.86 & 0.42 \\
\hline & Post-monsoon & 0.14 & -0.89 & 0.81 & 0.37 \\
\hline \multirow[t]{3}{*}{$\mathrm{CAI}-\mathrm{II}, \mathrm{meq} / \mathrm{L}$} & Pre-monsoon & 0.70 & -0.43 & 4.33 & 1.13 \\
\hline & monsoon & 0.52 & -0.50 & 2.36 & 0.86 \\
\hline & Post-monsoon & 0.56 & -0.46 & 2.44 & 0.89 \\
\hline \multirow[t]{3}{*}{$\mathrm{RSC}, \mathrm{meq} / \mathrm{L}$} & Pre-monsoon & -10.6 & -37.6 & -1.75 & 9.91 \\
\hline & Monsoon & -9.86 & -26.6 & 1.81 & 8.92 \\
\hline & Post-monsoon & -10.1 & -30.5 & 2.74 & 9.24 \\
\hline \multirow[t]{3}{*}{$\mathrm{GR}-\mathrm{I}, \mathrm{meq} / \mathrm{L}$} & Pre-monsoon & 0.674 & 0.368 & 0.933 & 0.169 \\
\hline & Monsoon & 0.656 & 0.410 & 0.896 & 0.164 \\
\hline & Post-monsoon & 0.656 & 0.417 & 0.903 & 0.166 \\
\hline \multirow[t]{3}{*}{ GR_II, meq/L } & Pre-monsoon & 0.583 & 0.325 & 0.864 & 0.138 \\
\hline & Monsoon & 0.587 & 0.241 & 0.858 & 0.152 \\
\hline & Post-monsoon & 0.572 & 0.297 & 0.859 & 0.132 \\
\hline
\end{tabular}

monsoon, monsoon, and post-monsoon seasons, respectively. In this regard, $37.50 \%$ samples in all three seasons are observed in unsuitable category. When the concentration of $\mathrm{Na}^{+}$ion is high in irrigation water, clay particles observe $\mathrm{Na}^{+}$displacing $\mathrm{Ca}^{2+}$ and $\mathrm{Mg}^{2+}$ which eventually reduce the soil permeability, and during wet conditions, water circulation is restricted, and the soil becomes hard when it becomes dry (Jafar Ahamed et al. 2013; Kumar et al. 2007).

\section{Residual sodium carbonate}

The high content of bicarbonates and carbonate in excess of $\mathrm{Ca}^{2+}$ and $\mathrm{Mg}^{2+}$ is expressed as the RSC and influence the groundwater for irrigation (Ragunath 1987; Eaton 1950). $\mathrm{Ca}^{2+}$ and $\mathrm{Mg}^{2+}$ ions in soil are precipitated by
$\mathrm{HCO}_{3}{ }^{-}$and $\mathrm{CO}_{3}{ }^{-}$resulting in the high content of sodium ions (Karanth 1987). According to USSL (1954), groundwater of RSC values $<1.25 \mathrm{meq} / \mathrm{L}$ is safe for irrigation, its marginal lies between 1.25 and $2.50 \mathrm{meq} / \mathrm{L}$, and a value $>2.5 \mathrm{meq} / \mathrm{L}$ is not suitable for irrigation (Table 9). All the samples in pre-monsoon have RSC value $<1.25 \mathrm{meq} / \mathrm{L}$, $95.80 \%$ samples in monsoon and post-monsoon are safe for irrigation, and $4.20 \%$ in monsoon and post-monsoon season fall in the field of doubtful and unsuitable category. Approximately, $95 \%$ samples in all three seasons are safe for irrigation with respect to $\mathrm{RSC}$.

\section{Chloro-alkaline indices}

An important factor affecting the groundwater chemistry is ion exchange which is a hard task for hydrogeologists, 
Fig. 5 Classification of groundwater based on USSL diagram

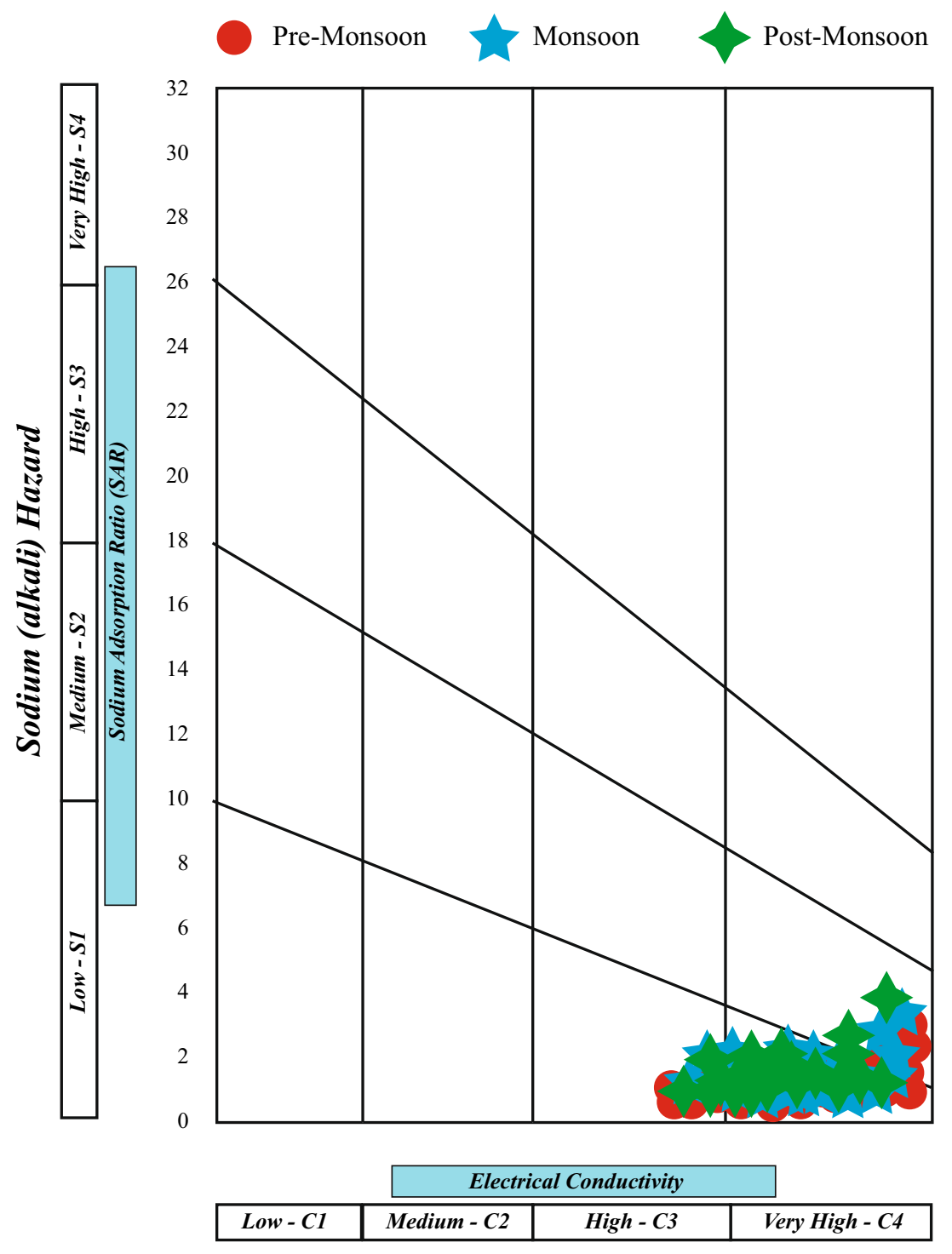

Salinity Hazard since it regulates the transport of pollutant chemicals in both aquifer and soils ( $\mathrm{Li}$ et al. 2013). The ion exchange process can be known by chloro-alkaline indices (CAI I and CAI II), also known as a Schoeller index (Schoeller 1977). The CAI can be either positive or negative, if $\mathrm{Na}^{+}$ and $\mathrm{K}^{+}$are exchanged with water with $\mathrm{Ca}^{2+}$ and $\mathrm{Mg}^{2+}$ in the rock/aquifer soil, both of the above indices are positive indicating the base-exchange phenomenon. If $\mathrm{Ca}^{2+}$ and $\mathrm{Mg}^{2+}$ are exchanged with water with $\mathrm{Na}^{+}$and $\mathrm{K}^{+}$in aquifer medium, the indices will be negative, which indicates chloro-alkaline disequilibrium and the reaction as a cation-anion exchange reaction (Table 8). In the present study, $66.70 \%$ of groundwater samples in all three seasons show positive values indicating reverse ion exchange, and only $33.30 \%$ samples having negative value have normal ion exchange. The above observation reveals that reverse ion exchange is the leading process in the groundwater.

\section{Potential salinity}

The concentration of highly soluble salts increases the salinity of the soils, whereas low soluble salts precipitate and accumulate into the soil for successive irrigation (Ogunfowokan et al. 2013). The suitability of water for irrigation is described by Doneen (1964) based on potential salinity. Potential salinity depends on the concentration of $\mathrm{Cl}^{-}$as well as $\mathrm{SO}_{4}{ }^{2-}$. The higher the potential salinity value, high will be $\mathrm{Cl}^{-}$concentration. The average potential salinity value (Table 8 ) in the study area is $12.94 \mathrm{meq} / \mathrm{L}$ (pre-monsoon), $10.25 \mathrm{meq} / \mathrm{L}$ (monsoon), and $10.76 \mathrm{meq} / \mathrm{L}$ (post-monsoon). The results indicate that 
Table 9 Classification of groundwater upon different irrigation parameters

\begin{tabular}{|c|c|c|c|c|c|c|c|}
\hline \multirow[t]{2}{*}{ Parameters } & \multirow[t]{2}{*}{ Category } & \multicolumn{3}{|c|}{ Total number of samples } & \multicolumn{3}{|c|}{ Percentage of samples } \\
\hline & & Pre-monsoon & Monsoon & Post-monsoon & Pre-monsoon & Monsoon & Post-monsoon \\
\hline \multicolumn{8}{|c|}{ EC, $\mu \mathrm{S} / \mathrm{cm}($ Wilcox 1955) } \\
\hline$<250$ & Low & - & - & - & - & - & - \\
\hline $250-750$ & Medium & - & - & - & - & - & - \\
\hline $750-2250$ & High & 9 & 9 & 8 & 37.50 & 37.50 & 33.30 \\
\hline$>2250$ & Very high & 15 & 15 & 16 & 62.50 & 62.50 & 66.70 \\
\hline \multicolumn{8}{|c|}{ SAR, meq/L (Richards 1954) } \\
\hline $0-6$ & No problems & 18 & 16 & 16 & 75.00 & 66.70 & 66.70 \\
\hline $6-9$ & Increase problems & 3 & 5 & 5 & 12.50 & 20.80 & 20.80 \\
\hline$>9$ & Severe problems & 3 & 3 & 3 & 12.50 & 12.50 & 12.50 \\
\hline \multicolumn{8}{|c|}{ Percent sodium, \% (Wilcox 1955) } \\
\hline$<20$ & Excellent & 2 & 1 & 1 & 8.40 & 4.20 & 4.20 \\
\hline $20-40$ & Good & 10 & 9 & 9 & 41.60 & 37.50 & 37.50 \\
\hline $40-60$ & Permissible & 9 & 10 & 10 & 37.50 & 41.60 & 41.60 \\
\hline $60-80$ & Doubtful & 3 & 4 & 4 & 12.50 & 16.70 & 16.70 \\
\hline$>80$ & Unsuitable & - & - & - & - & - & - \\
\hline \multicolumn{8}{|c|}{ RSC, meq/L (Richards 1954) } \\
\hline$<1.25$ & Good & 24 & 23 & 23 & 100 & 95.80 & 95.80 \\
\hline $1.25-2.50$ & Doubtful & - & 1 & - & - & 4.20 & - \\
\hline$>2.50$ & Unsuitable & - & - & 1 & - & - & 4.20 \\
\hline \multicolumn{8}{|c|}{ Kelly's ratio, meq/L } \\
\hline$<1$ & Suitable & 18 & 18 & 18 & 75.00 & 75.00 & 75.00 \\
\hline$>1$ & Unsuitable & 6 & 6 & 6 & 25.00 & 25.00 & 25.00 \\
\hline \multicolumn{8}{|c|}{ Magnesium hazard, meq/L } \\
\hline$<50$ & Suitable & 15 & 18 & 20 & 62.50 & 75.00 & 83.30 \\
\hline$>50$ & Unsuitable & 9 & 6 & 4 & 37.50 & 25.00 & 16.70 \\
\hline
\end{tabular}

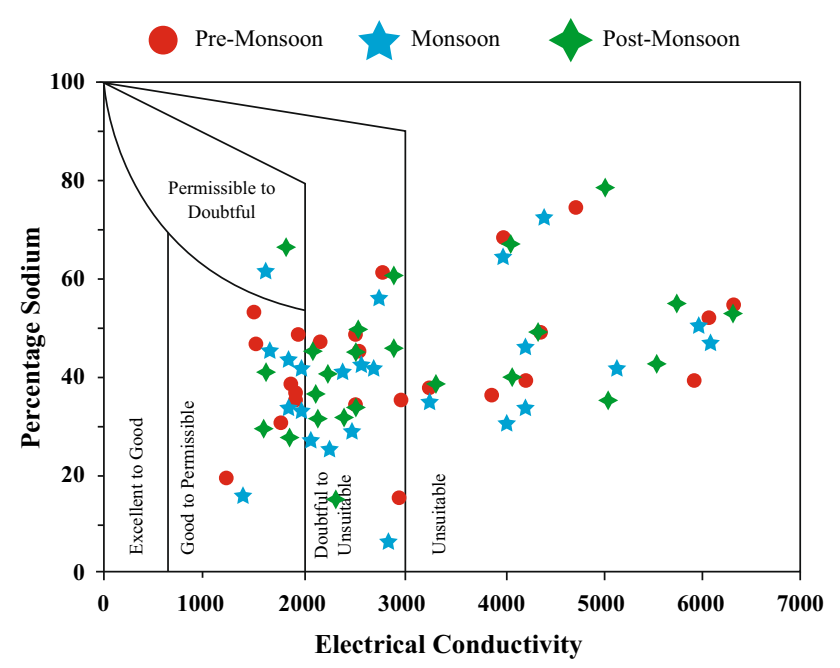

Fig. 6 Rating of groundwater samples in relation to percent sodium versus electrical conductivity (Wilcox diagram) groundwater has high PS value and is not suitable for irrigation.

\section{Magnesium hazard}

The magnesium hazard value is used to estimate the groundwater for irrigation, having an excess level of $\mathrm{Mg}^{2+}$ which damages soil structure, when water contains high $\mathrm{Na}^{+}$and high salinity (Rao et al. 2012). Generally, $\mathrm{Ca}^{2+}$ and $\mathrm{Mg}^{2+}$ maintain a state of equilibrium in the water, but they do not behave identically in soil systems. If $\mathrm{MH}$ value exceeds $>50 \mathrm{meq} / \mathrm{L}$, it is considered to be harmful to plant growth and is not suitable for irrigation. From the analytical data, the $\mathrm{MH}$ value ranges from 23.71 to $70.88 \mathrm{meq} / \mathrm{L}$, 29.79-72.39 meq/L, and 26.58-65.31 meq/L for pre-monsoon, monsoon, and post-monsoon seasons, respectively (Table 8). Based on the above criteria, 37.50, 25.00, and $16.70 \%$ samples from pre-monsoon, monsoon, and post- 
monsoon seasons, respectively, are not suitable for agricultural purposes.

\section{Kelly's ratio}

Groundwater is classified for irrigation based on Kelly's ratio. Kelly (1946) and Paliwal (1967) calculated this parameter, when $\mathrm{Na}^{+}$is measured against $\mathrm{Ca}^{2+}$ and $\mathrm{Mg}^{2+}$ ions. Water with $\mathrm{KR}>1.0$ indicates an excess level of $\mathrm{Na}^{+}$and greater than 3 is not suitable. About $75 \%$ samples in all three seasons are safe for irrigation $(<1.0 \mathrm{meq} / \mathrm{L})$, and $25.00 \%$ of the samples are unsuitable, having a KR value $>1.0$ (Table 9).

\section{Permeability index}

Permeability is greatly influenced by $\mathrm{Na}^{+}, \mathrm{Ca}^{2+}, \mathrm{Mg}^{2+}$, $\mathrm{Cl}^{-}$, and $\mathrm{HCO}_{3}{ }^{-}$contents of the soil, and it is affected by long-term use of irrigation water, with high salt content (Rao et al. 2012; Kumar et al. 2007). Doneen (1964) gave a criteria for assessing the suitability of groundwater for irrigation based on PI. On the basis of PI, it can be classified into three classes: class I, suitable (100\% maximum permeability), class II, marginal (75\% maximum permeability), and class III, unsuitable ( $25 \%$ maximum permeability). The PI value in the study area ranges from 25.46 to $80.52 \%, 19.31-82.40 \%$, and 24.13 to $84.36 \%$ for premonsoon, monsoon, and post-monsoon seasons, respectively (Table 6). About 70.00 and $67.00 \%$ of samples from pre-monsoon, monsoon, and post-monsoon seasons fall in class I and $12.50 \%$ and $8.30 \%$ samples fall in the class II category (Fig. 7), indicating that the water is suitable for irrigation and the remaining are unsuitable.

\section{Conclusion}

The groundwater samples of the Amaravathi River basin have been carried out to assess the suitability for drinking and irrigation purposes. The data on parameter-analyzed water samples show elevated level of salt contents, which results in unsuitable for drinking purposes compared with WHO and BIS standards. The dominant constituents of groundwater are as follows: $\mathrm{Na}^{+}>\mathrm{Ca}^{2+}>\mathrm{Mg}^{2+}>\mathrm{K}^{+}$ for cation and $\mathrm{Cl}^{-}>\mathrm{HCO}_{3}{ }^{-}>\mathrm{SO}_{4}{ }^{2-}>\mathrm{NO}_{3}{ }^{-}$for anions. Water facies classification shows that $62 \%$ of groundwater samples in all three seasons belong to mixed $\mathrm{Ca}^{2+}-\mathrm{Mg}^{2+}$ $\mathrm{Cl}^{-}$type followed by $\mathrm{Ca}^{2+}-\mathrm{Cl}^{-}$and $\mathrm{Na}^{+}-\mathrm{Cl}^{-}$type. Evaporation-crystallization is the dominant factor with slight rock weathering dominance as suggested by Gibbs diagram. Some good positive correlation of $\mathrm{Na}^{+}, \mathrm{Ca}^{2+}$ and $\mathrm{Mg}^{2+}$ with EC, TDS, TH, and $\mathrm{Cl}^{-}$is observed, respectively. According to irrigational quality parameters, $70 \%$

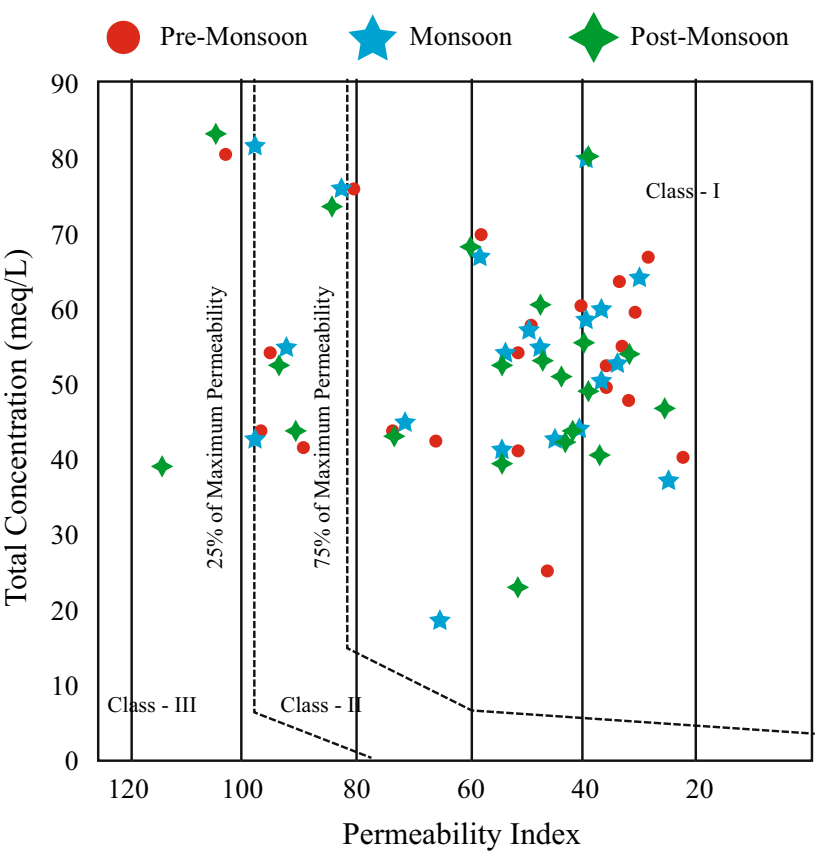

Fig. 7 Classification of irrigation water based on permeability index

of samples are suitable for irrigation in all three seasons with respect to $\mathrm{KR}, \mathrm{MH}, \mathrm{RSC}$, and PI. From USSL and Wilcox diagram, $30 \%$ of the samples are unsuitable. The continuous usage of these groundwater with high $\mathrm{Na}^{+}, \mathrm{K}^{+}$, and $\mathrm{Cl}^{-}$leads to low crop yield, and which affects the soil and plant growth. Comparing the groundwater samples from the origin of Karur district, the downstream samples are over-exploited due to continuous mixing of dyeing effluents, municipal wastes, and dump of agricultural and textile wastes directly to the river during the past 11 years. The groundwater in the Amaravathi River basin is in a critical situation, and the government and policy makers should put attention to protect this natural resource from contamination; otherwise, some serious damage will happen to living beings in the future years.

Acknowledgments The authors are thankful to the University Grants Commission (UGC), New Delhi, for providing Major Research Fund (F. No.41-337/2012) and the members of the Management Committee and the Principal of Jamal Mohamed College for providing the necessary facilities. We are grateful to the anonymous reviewers who have offered their valuable suggestions to improve the manuscript.

\section{References}

Agarwal V, Jagetai M (1997) Hydrochemical assessment of groundwater quality in Udaipur city, Rajasthan, India. In: Proceedings of national conference on dimensions of environmental stress in India. Department of geology, MS University, Baroda, India, pp 151-154 
Anithamary I, Ramkumar T, Venkatramanan S (2012) Application of statistical analysis for the hydrogeochemistry of saline groundwater in Kodiakarai, Tamilnadu, India. J Coastal Res 281:89-98

APHA (2005) Standard methods for the examination of water and wastewater, 21st edn. American Public Health Association, Washington DC

Arveti N, Sarma MRS, Aitkenhead-Peterson JA, Sunil K (2011) Fluoride incidence in groundwater: a case study from Talupula, Andhra Pradesh, India. Environ Monit Assess 172:427-443

Awadh SM, Ahmed RM (2013) Hydrochemistry and pollution probability of selected sites along the Euphrates River, Western Iraq. Arab J Geosci 6:2501-2518

BIS (2003) Indian standards specification for drinking water 15:10500. Bureau of Indian Standards, New Delhi

Bozdag A, Gocmez G (2013) Evaluation of groundwater quality in the Cihanbeyli basin, Konya, Central Anatolia, Turkey. Environ Earth Sci 69:921-937

CGWB (2008) District groundwater brochure Karur district, Tamil nadu. Central Ground Water Board, Chennai

Davis SN, De Wiest RJM (1966) Hydrogeology, vol 463. Wiley, New York

Dixon W, Chiswell B (1992) The use of hydrochemical sections to identify recharge areas and saline intrusions in alluvial aquifers, southeast Queensland, Australia. J Hydrol 130:299-338

Doneen LD (1964) Notes on water quality in Agriculture Published as a Water Science and Engineering Paper 4001. Department of Water Science and Engineering, University of California

Eaton FM (1950) Significance of carbonate irrigation water. Soils Sci 69:123-133

Elango L, Kannan R, Kumar Senthil (2003) Major ion chemistry and identification of hydrogeochemical process of groundwater in a part of Kancheepuram District, Tamilnadu, India. J Environ Geosci 10:157-166

Elkrail A, Kheir O, Shu L, Zhenchun H (2004) Hydrogeology of the northern Gezira area, Central Sudan. J Spat Hydrol 4:1-11

Foster S (1998) Groundwater assessing vulnerability and promotion protection of a threatened resource. In: Proceedings of the 8th Stockholm water symposium, Sweden, pp 79-90

Freeze RA, Cherry JA (1979) Groundwater. Prentice-Hall Inc, Englewood Cliffs

Gibbs RJ (1970) Mechanisms controlling world water chemistry. Science 17:1088-1090

Gnanachandrasamy G, Ramkumar T, Venkatramanan S, Vasudevan S, Chung SY, Bagyaraj M (2014) Accessing groundwater quality in lower part of Nagapattinam district, Southern India: using hydrogeochemistry and GIS interpolation techniques. Appl Water Sci. doi:10.1007/s13201-014-0172-z

Guler C, Thyne GD (2004) Hydrologic and geologic factors controlling surface and groundwater chemistry in Indian Wells-Owens valley area, Southeastern California, USA. J Hydrol 285:177-198

Gupta S, Maheto A, Roy P, Datta JK, Saha RN (2008) Geochemistry of groundwater, Burdwan district, West Bengal, India. Environ Geol 53:1271-1282

Haie Naim, Gaspar Machado JBQA, Rui Pereira M, Andrew Keller A (2011) Effective efficiency in water resources management using efficiency elasticity index. Water Environ J 25:532-539

Hem JD (1985) Study and interpretation of the chemical characteristics of natural water. USGS Water Supply Paper 2254:117-120

Hutak PF (2000) Regional trends in nitrate content of Texas groundwater. J Hydrogeol 228:37-47

Jafar Ahamed A, Ananthakrishnan S, Loganathan K, Manikandan K (2013) Assessment of groundwater quality for irrigation use in Alathur Block, Perambalur District, Tamilnadu, South India. Appl Water Sci 3:763-771
Jalali M (2006) Chemical characteristics of groundwater in parts of mountainous region, Alvand, Hamadan, Iran. Environ Geol $51: 433-446$

Karanth KR (1987) Ground water assessment development and management. Tata McGraw-Hill, Noida, p 720

Kelly WP (1946) Permissible composition and concentration of irrigation waters. In: Proceeding American Society of Civil Engineering

Kim Y, Kim K (2013) Hydrogeochemical and isotopic study of the Kumho River, Korea: implications for anthropogenic and seasonal effects. Environ Earth Sci 68:2051-2064

Kim K, Rajmohan N, Kim HJ, Kim SH, Hwang GS, Yun ST, Gu B, Cho MJ, Lee SH (2005) Evaluation of geochemical processes affecting groundwater chemistry based on mass balance approach: a case study in Namwon, Korea. Geochem J 39:357-369

Kortatsi BK (2007) Hydrochemical framework of groundwater in the Ankobra basin, Ghana. Aquatic Geochem 13:41-74

Kumar M, Kumari K, Ramanathan AL, Saxena R (2007) A comparative evaluation of groundwater suitability for irrigation and drinking purposes in two intensively cultivated districts of Punjab, India. Environ Geol 53:553-574

Kumarasamy P, Alaguraja P, Deepasaraswathi M, Sekar M, Muthuveerran P, Yuvaraj D, Thirunavukkarasu A, Arthur J, Sames R (2011) Soil suitability and water quality study in Tirupur areas using geographic information system techniques. Int J Earth Sci Eng 4:85-97

Kundu N, Panigrahi MK, Tripathy S, Munshi S, Powell MA, Hart BR (2001) Geo-chemical appraisal of fluoride contamination of groundwater in the Nayagarh District of Orissa, Indian. Environ Geol 41:451-460

Langenegger O (1990) Ground water quality in rural areas of western Africa, UNDP project INT/81/026:10

Li P, Wu J, Qian H (2013) Assessment of groundwater quality for irrigation purposes and identification of hydrogeochemical evolution mechanisms in Pengyang County, China. Environ Earth Sci 69:2211-2225

Loizidou M, Kapetanios EG (1993) Effect of leachate from landfills on underground water quality. Sci Total Environ 128:69-81

Mamatha P, Rao SM (2010) Geochemistry of fluoride rich groundwater in Kolar and Tumkur districts of Karnataka. Environ Earth Sci 61:131-142

Marghade D, Malpe DB, Zade AB (2012) Major ion chemistry of shallow groundwater of a fast growing city of Central India. Environ Monit Assess 184:2405-2418

Meenakshi RC (2006) Fluoride in drinking water and its removal. J Hazard Mater B 137:456-463

Ogunfowokan AO, Obisanya JF, Ogunkoya OO (2013) Salinity and sodium hazards of three streams of different agricultural land use systems in Ile-Ife, Nigeria. Appl Water Sci 3:19-28

Paliwal KV (1967) Effect of gypsum application on the quality if irrigation waters. Madras Agric J 59:646-647

Piper AM (1944) A graphical procedure in the geochemical interpretation of water analysis. Am Geophys Union Trans 25:914-928

Prasanna MV, Chidambaram S, Senthil Kumar G, Ramanathan AL, Nainwal HC (2010) Hydrogeochemical assessment of groundwater in Neyveli Basin, Cuddalore District, South India. Arab J Geosci 4:319-330

Rafique T, Naseem S, Bhanger MI, Usmani TH (2008) Fluoride ion contamination in the groundwater of Mithi sub-district, the Thar Desert, Pakistan. Environ Geol 56:317-326

Rafique T, Naseem S, Usmani TH, Bashir E, Ahmed Khan F, Bhanger MI (2009) Geochemical factors controlling the occurrence of high fluoride groundwater in the Nagar Parkar area, Sindh, Pakistan. J Hazard Mater 171:424-430 
Ragunath HM (1987) Groundwater, 2nd edn. Wiley Eastern Ltd., New Delhi, pp 344-369

Raju NJ, Shukla UK, Ram P (2011) Hydrogeochemistry for the assessment of groundwater quality in Varanasi: a fast-urbanizing center in Uttar Pradesh, India. Environ Monit Assess 173:279-300

Ramesam V, Rajagopalan KJ (1985) Fluoride ingestion into the natural waters of hard-rock areas, peninsular India. J Geol Soc 26:125-132

Ramesh K, Elango L (2012) Groundwater quality and its suitability for domestic and agricultural use in Tondiar river basin, Tamil Nadu, India. Environ Monit Assess 184:3887-3899

Ramesh K, Vennila S (2012) Hydrochemical analysis and evaluation of groundwater quality in and around Hosur, Krishnagiri District, Tamil Nadu, India. Int J Res Chem Environ 2:113-122

Rao NS, Rao PS, Reddy GV, Nagamani M, Vidyasagar G, Satyanarayana NLVV (2012) Chemical characteristics of groundwater and assessment of groundwater quality in Varaha River Basin, Visakhapatnam District, Andhra Pradesh, India. Environ Monit Assess 184:5189-5214

Ravikumar P, Aneesul Mehmood M, Somashekar RK (2013) Water quality index to determine the surface water quality of Sankey tank and Mallathahalli lake, Bangalore urban district, Karnataka, India. Appl Water Sci 3:247-261

Renganathan L (2014) Water table plummets to new low in Karur. The Hindu. http://www.thehindu.com/. Accessed 13 Jan 2014

Richards LA (1954) Diagnosis and improvement of saline alkali soils: agriculture. Handbook 60, US Department of Agriculture, Washington DC

Saleem R (2007) Groundwater management-emerging challenges. Water Dig 1:121-128

Sankararamakrishnan N, Sharma AK, Iyengar L (2008) Contamination of nitrate and fluoride in groundwater along the Ganges alluvial plain of Kanpur district, Uttar Pradesh, India. Environ Monit Assess 146:375-382

Sarath Prasanth SV, Magesh NS, Jitheshlal KV, Chandrasekar N, Gangadhar K (2012) Evaluation of groundwater quality and its suitability for drinking and agricultural use in the coastal stretch of Alappuzha District, Kerala, India. Appl Water Sci 2:165-175

Sawyer GN, McCarthy DL (1967) Chemistry of sanitary engineers, 2nd edn. McGraw Hill, New York, p 518

Schoeller H (1977) Geochemistry of groundwater. In: Groundwater studies-an international guide for research and practice, Supplement No. 3 to Groundwater Studies. UNESCO Tech. Papers Hydrol. 7. UNESCO, Paris

Sharma P, Sarma HP, Mahanta C (2012) Evaluation of groundwater quality with emphasis on fluoride concentration in Nalbari district, Assam, Northeast India. Environ Earth Sci 65:2147-2159

Shin WJ, Ryu JS, Park Y, Lee KS (2011) Chemical weathering and associated $\mathrm{CO}_{2}$ consumption in six major river basins, South Korea. Geomorphology 129:334-341

Singh KP, Malik A, Mohan D, Singh VK, Sinha S (2006) Evaluation of groundwater quality in Northern Indo-Gangetic alluvium region. Environ Monit Assess 112:211-230
Singh AK, Mondal GC, Singh TB, Singh S, Tewary BK, Sinha A (2012) Hydrogeochemical processes and quality assessment of groundwater in Dumka and Jamtara districts, Jharkhand, India. Environ Earth Sci 67:2175-2191

Sivasankar V, Gomathi R (2009) Fluoride and other water quality parameters in the groundwater samples of Pettaivaithalai and Kulithalai areas of Tamil Nadu, Southern India. Water Qual Expo Health 1:123-134

Sparks DL (2003) Environmental Soil Chemistry, 2nd edn. Academic Press, Oxford, p 352

Srinivas Y, Hudson Oliver D, Stanley Raj A, Chandrasekar N (2013) Evaluation of groundwater quality in and around Nagercoil town, Tamilnadu, India: an integrated geochemical and GIS approach. Appl Water Sci 3:631-651

Tay CK (2012) Hydrochemistry of groundwater in the SaveluguNanton District, Northern Ghana. Environ Earth Sci 67:2077-2087

Thomson Jacob C, Azariah J, Viji Roy AG (1999) Impact of textile industries on river Noyyal and riverine groundwater quality of Tirupur, India. Poll Res 18:359-368

Todd DK (1980) Groundwater hydrology, 2nd edn. Wiley, New York UNEP (1999) United Nation Environmental Programme. Earth scan, Global Environmental Outlook, United Kingdom: 2000

United Nations General Assembly (2004) 58th Session, A/Res/58/ 217. http://www.un.org/waterforlifedecade/reference.html. Accessed 9 Feb 2004

US Salinity Laboratory (1954) Diagnosis and improvement of saline and alkaline soils. Agriculture Handbook No. 60 USDA

Vasanthavigar M, Srinivasamoorthy K, Prasanna MV (2013) Identification of groundwater contamination zones and its sources by using multivariate statistical approach in Thirumanimuthar subbasin, Tamil Nadu, India. Environ Earth Sci 68:1783-1795

Viswanathan G, Jaswantha A, Gopalakrishnan S, Siva ilango S (2009) Mapping of fluoride endemic areas and assessment of fluoride exposure. Sci Total Environ 407:1579-1587

Viswanathan G, Gopalakrishnan S, Siva ilango S (2010) Assessment of water contribution on total fluoride intake of various age groups of people in fluoride endemic and non-endemic areas of Dindigul District, Tamil Nadu, South India. Water Res 44:6186-6200

Wang Y, Jiao JJ (2012) Origin of groundwater salinity and hydrogeochemical processes in the confined Quaternary aquifer of the Pearl River Delta, China. J Hydrol 438-439:112-124

WHO (2005) International standards for drinking water. World Health Organization, Geneva

Wilcox LV (1955) Classification and use of irrigation waters. USDA, Circular 969, Washington, DC

Yu JY, Park Y (2004) Sulphur isotopic and chemical compositions of the natural waters in the Chuncheon area, Korea. Appl Geochem 19:843-853

Zhang J, Huang WW, Létolle R, Jusserand C (1995) Major element chemistry of the Huanghe (Yellow River), China-weathering processes and chemical fluxes. J Hydrol 168:173-203 